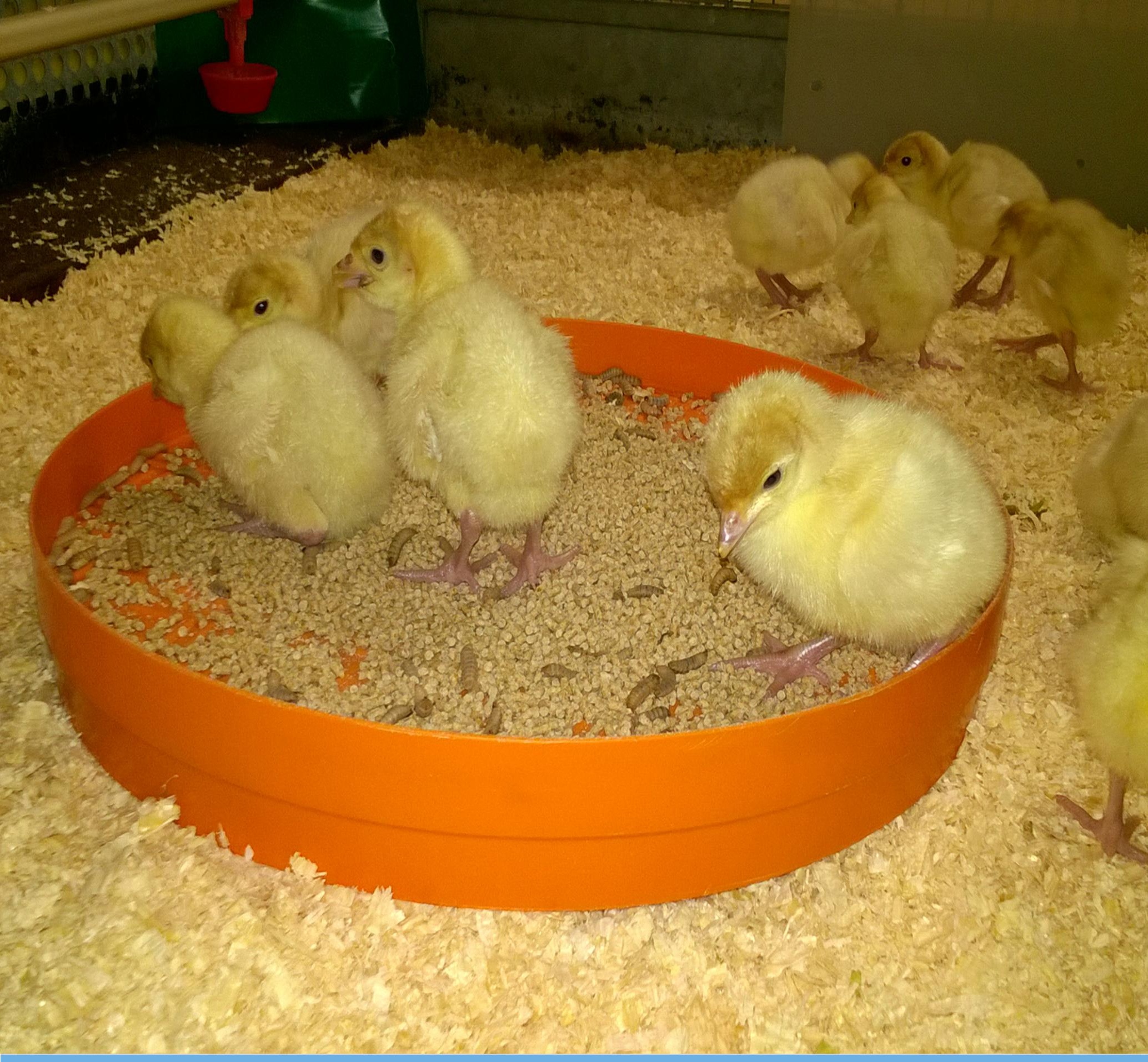

\title{
Insects for turkeys
}

Insecten voor kalkoenen

T.G.C.M. van Niekerk

T. Veldkamp 



\section{Insects for turkeys}

Insecten voor kalkoenen

T.G.C.M. van Niekerk \& T. Veldkamp

Wageningen Livestock Research, dept. Animal welfare

Wageningen Livestock Research, dept. Animal nutrition

This research was conducted by Wageningen Livestock Research, commissioned by the Steering Committee for Mutilations in Poultry and funded by the Ministry of Economic Affairs in the Agri-Food top sector (PPS

'Poultry4Food', AF-12048, project number BO-22.04-003-004)

Wageningen Livestock Research

Wageningen, October 2017

Report 1050 
Van Niekerk, T.G.C.M. \& T. Veldkamp, 2017. Insects for turkeys; Insecten voor kalkoenen. Wageningen Livestock Research, Report 1050.

Samenvatting: In een proef met 14 hokken met in elk 20 kalkoenkuikens (haantjes, onbehandeld) is gekeken naar het effect van het voeren van $12 \%$ insectenlarven (Black Soldier Fly) op technische resultaten en gedrag. De dieren werden tot 5 weken leeftijd gehouden. De met insectenlarven gevoerde groepen aten meer, groeiden harder, hadden een betere voerconversie en een hoger eindgewicht vergeleken de controledieren. Uitval was niet verschillend tussen beide behandelingen. Vergeleken met de controle hadden ze minder veerschade en minder verwondingen en vertoonden wat minder agressie, maar. Verder vertoonden ze minder scharrelgedrag in de derde en vijfde week vergeleken met de controlegroepen en dronken minder. Daarentegen hadden ze op vijf weken leeftijd wat meer voetzoollaesies dan de controledieren, terwijl de strooiselkwaliteit niet verschilde tussen beide groepen. Concluderend kan gesteld worden dat het voeren van insectenlarven een klein voordeel opleverde, maar het probleem van beschadigend pikgedrag niet oploste.

Summary: In a trial with 14 pens with in each 20 turkey pullets (males, not treated) research has been conducted to the effect of feeding 12\% insect larvae (Black Soldier Fly) on technical results and behaviour. The birds were kept until 5 weeks of age. The larvae fed groups ate less, had a higher growth rate, a better feed conversion ratio and a higher body weight at 5 weeks of age. Mortality was not different between the treatments. Compared to the controls the BSF larvae fed birds had less feather damage and less skin damage and performed less aggressive behaviour. Also they performed less foraging behaviour in the third and fifth week compared to the controls and a lower water intake. On the other hand at five weeks of age the BSF larvae fed birds had more footpad lesions than the controls, although litter quality did not differ between the treatments. In conclusion it can be stated that feeding insect larvae does give small advantages, but does not solve the problem of injurious pecking.

This report can be downloaded for free at https://doi.org/10.18174/424505 or at www.wur.nl/livestock-research (under Wageningen Livestock Research publications).

(C) 2017 Wageningen Livestock Research

P.O. Box 338, 6700 AH Wageningen, The Netherlands, T +31 (0)317 483953 ,

E info.livestockresearch@wur.nl, www.wur.nl/livestock-research. Wageningen Livestock Research is part of Wageningen University \& Research.

All rights reserved. No part of this publication may be reproduced and/or made public, whether by print, photocopy, microfilm or any other means, without the prior permission of the publisher or author.

The ISO 9001 certification by DNV underscores our quality level. All our research commissions are in line with the Terms and Conditions of the Animal Sciences Group. These are filed with the District Court of Zwolle. 


\section{Table of contents}

$\begin{array}{ll}\text { Foreword } & 5\end{array}$

$\begin{array}{ll}\text { Summary } & 7\end{array}$

$\begin{array}{ll}\text { Samenvatting } & 9\end{array}$

1

$\begin{array}{ll}\text { Introduction } & 11\end{array}$

1.1 Aim of the project $\quad 11$

2

$\begin{array}{ll}\text { Materials and method } & 12\end{array}$

2.1 Animals 12

2.2 Accommodation $\quad 12$

2.3 Feed 12

2.4 Management 13

2.4.1 Water 13

2.4.2 Lighting 13

2.4.3 Climate 13

2.4.4 Vaccinations 13

2.5 Observation $\quad 13$

2.5.1 Feed 13

2.5.2 Growth performance 13

$\begin{array}{ll}2.5 .3 \text { Exterior } & 14\end{array}$

2.5.4 Behavioural observations 14

2.5 .5 Litter quality $\quad 15$

$\begin{array}{lll}2.6 & \text { Statistical analysis } & 16\end{array}$

$\begin{array}{llr}3 & \text { Results and Discussion } & 17\end{array}$

$\begin{array}{lll}3.1 & \text { General } & 17\end{array}$

$\begin{array}{lll}3.2 & \text { Diet analyses } & 17\end{array}$

3.3 Supply and consumption of BSF larvae 18

$\begin{array}{lll}3.4 & \text { Growth performance } & 19\end{array}$

$\begin{array}{lll}3.5 & \text { Exterior } & 21\end{array}$

$\begin{array}{lll}3.6 & \text { Behavioural observations } & 21\end{array}$

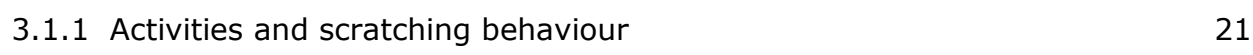

3.1.1 Feather pecking and aggressive pecking $\quad 26$

$\begin{array}{lll}3.7 & \text { Visual litter quality } & 30\end{array}$

4

$\begin{array}{ll}\text { Conclusions } & 31\end{array}$

$\begin{array}{ll}\text { References } & 32\end{array}$

Appendix 1 Feed composition of experimental turkey diet during phase I 33

Appendix 2 Feed composition of experimental turkey diet during phase II 34

Appendix 3 Composition turkey premix 35

Appendix 4 Certificate of analysis life frozen Black Soldier Fly 36

$\begin{array}{lll}\text { Appendix } 5 & \text { Light management } & 37\end{array}$

$\begin{array}{lll}\text { Appendix } 6 & \text { Room/local temperature settings } & 38\end{array}$ 



\section{Foreword}

The Dutch government is intending to ban all mutilations on animals. This also includes beak treatment of turkeys. Injurious pecking behaviour is a severe problem in laying hens and turkeys. Already for many years research has been conducted to solve this problem. However, measures that are successful in laying hens, do not have sufficient effect in turkeys. This can be explained by the fat that turkeys are a different type of species. A literature study on the natural behaviour of turkeys indicated that feeding strategies could be a way to reduce injurious pecking behaviour in turkeys. As turkey poults in the wild feed themselves with insects during the first two weeks of their life, research was set up to mimic this and see what the effects would be on pecking behaviour of turkeys in the first 5 weeks of their life. The underlying report is presenting the results of this study.

This study was in fact the very first one to use insect larvae for turkeys. Although a solution for injurious pecking in turkeys has not yet been found, we hope this research is a useful step towards understanding and solving the problem.

The authors like to thank Hendrix Genetics for providing the turkey poults and Protix for supplying the Black Soldier Fly larvae. Also we would like to thank the Dutch Steering Committee mutilations and the Dutch Turkey producers for the financial support of this trial.

Thea van Niekerk

Teun Veldkamp

September 2017 


\section{Summary}

Damaging pecking behaviour is a severe problem in laying hens and turkeys. Measures that are successful in laying hens, do not have sufficient effect in turkeys.

An important question is: What is the ideal early rearing for commercial turkeys to stimulate the development of natural (scratching) behaviour and subsequently direct their pecking behaviour to the ground? Wild turkeys grow up with insects during the first two weeks of life. This is a huge contrast with the current physical form (crumbs or small pellets) of diets fed to day-old turkey poults. A more lively diet may improve natural (scratching, ranging, foraging) behaviour in turkey poults. The project had the following aims:

1. Stimulate the scratching, foraging, ranging behaviour of young turkey poults in order to avoid damaging pecking behaviour.

2. Supplement the diet with live insects (animal protein) to avoid damaging pecking behaviour in non-beak treated turkeys.

The project focussed on the first phase of growing turkeys, i.e. 0 to 5 weeks of age.

In one room of a research facility 14 floor pens $\left(1.5 \mathrm{~m}^{2} /\right.$ pen) each contained 20 day-old turkey poults (males, Hybrid Converter). The birds were kept until 35 days of age. There were 2 treatments with 7 replicates (pens) per treatment:

CONTROL: standard feed

- $\quad$ INSECTS: each day the birds got a bucket with live? insect larvae (Black Soldier Fly, BSF). The BSF larvae intake was calculated to be $10 \%$ of the expected daily feed intake. Additionally the birds got a modified feed, in which the nutritional composition was adapted so that both control and insect groups got the same daily nutrients, based on a similar expected feed intake.

Body weight (BW) of turkeys per pen was determined at 0, 7, 15, 21, 28 and 35 days of age. Feed use including the BSF larvae was determined per pen (provided feed minus remaining feed/BSF larvae). Body weight gain (BWG), average daily gain (ADG), feed conversion ratio (FCR), feed intake (FI), average daily feed intake (ADFI) were calculated on a pen basis from these data for the following periods: $0-7 d, 7-15 d, 15-21 d, 21-28 d, 28-35 d$, and $0-35 d$. Culling, mortality and health were recorded daily (including probable causes of culling, illness and deaths). At placement all chicks were weighed individually. Thereafter all birds were weighed individually once a week and at the same time scored for feather and skin damage, cleanliness and foot pad lesions. The behavioural observations were carried out using video recordings made in week 1, 3 and 5 in 4 different periods of the day: $10.00-11.00 \mathrm{~h}$ (before getting larvae), 11.00-12.00 h, 12.00-13.00 h and 18.00-19.00 h. Larvae were provided at $11.00 \mathrm{~h}$. The analysis of the video recordings was done in 2 different ways: Scan sampling foraging- and scratching behaviour and behaviour sampling feather pecking and aggressive pecking.

Directly from the start onwards the birds did eat the larvae very good and were very keen on it. All provided BSF larvae were consumed between one and two minutes after provision and no left-overs of BSF larvae were observed. Overall, daily FI of turkeys fed BSF larvae was significantly higher than FI of Controls, with consequently a higher ADG for the BSF larvae groups and a higher final body weight at 5 weeks of age ( 2190 vs. $2015 \mathrm{~g} ; P=0.003$ ). Feed conversion ratio of turkeys fed BSF larvae was significantly lower than feed conversion ratio of Control fed turkeys, especially in the period until 15 days of age.

Feather and skin damage was very limited in the first 3 weeks, with a tendency to be lower in the insect groups. In week 4 and 5 there was a significant difference in favour of the BSF larvae groups. Cleanliness of the feathers was not different in the first 2 weeks. In the third and $5^{\text {th }}$ week the control birds had a cleaner feather cover. In the $4^{\text {th }}$ week there was no difference.

The incidence of foot pad lesions increased over age. They were more frequent in the control group in the first 3 weeks, but after that there was no difference anymore. 
Birds fed BSF larvae performed less foraging related behaviour in the third and fifth week compared to the controls, whereas in the first week there was a tendency for more foraging related behaviour for the BSF larvae groups. For activities other than foraging no clear trends could be observed.

Although the differences were small, the provision of BSF larvae reduced aggressive pecking directed at the back and tail base. This effect was especially visible in periods of the day, where no BSF larvae were provided. In the period BSF larvae were provided no increase of aggression was seen due to possible competition for the BSF larvae. With regards to feather pecking no clear differences between the groups were found.

Visual litter quality was not affected by dietary treatment at $35 \mathrm{~d}$ of age.

Overall, we believe there are small but significant benefits of feeding live insects to turkey poults in terms of production and welfare, even though the benefits were not sufficiently large to solve the injuries pecking problem. 


\section{Samenvatting}

Beschadigend pikgedrag is een ernstig probleem in leghennen en kalkoenen. Maatregelen die succesvol zijn bij leghennen hebben echter onvoldoende effect bij kalkoenen.

Een belangrijke vraag is: Wat is de ideale vroege-opfok voor commerciële kalkoenen om het natuurlijke (scharrel-)gedrag te stimuleren en aldus hun pikgedrag meer op de grond te richten? Wilde kalkoenen voeden zich de eerste twee weken van hun leven met insecten. Dit is een enorm verschil met de huidige fysieke vorm (kruimels of kleine pellets) van het voer voor kalkoenkuikens. Een meer levendig dieet kan wellicht het natuurlijke (scharrel) gedrag van kalkoenkuikens verbeteren. Het doel van het project was tweeledig:

1. Stimuleren van scharrelgedrag van jonge kalkoenkuikens ter voorkoming van beschadigend pikgedrag.

2. Aanvullen van het voer met levende insecten (dierlijk eiwit) ter voorkoming van beschadigend pikgedrag in niet-snavelbehandelde kalkoenen.

Het project was gericht op de eerste fase van de opfok van vleeskalkoenen, m.n. 0 tot 5 weken leeftijd.

In een ruimte van een onderzoekstal werden 14 grondhokken geplaatst. In elk hok $\left(1,5 \mathrm{~m}^{2}\right)$ werden 20 eendagskalkoenkuikens (hanen, Hybrid Converter) geplaatst. De dieren werden gehouden tot 35 dagen leeftijd. Er waren twee behandelingen met 7 herhalingen (hokken) per behandeling:

CONTROLE: standaard voer

- $\quad$ INSECTEN: elke dag kregen de kalkoenen een bak met levende insectenlarven (Black Soldier Fly, BSF). De hoeveelheid insectenlarven werd berekend als $10 \%$ van de verwachte dagelijkse voeropname. Aanvullend kregen de kuikens een aangepast voer, waarin de samenstelling zodanig was aangepast, dat zowel controle als insectengroepen dagelijks dezelfde nutriënten kregen, gebaseerd op een verwachte gelijke voeropname. Individuele diergewichten (BW) van de kalkoenen per hok werd bepaald op 0, 7, 15, 21, 28 en 35 dagen leeftijd. Voerverbruik, inclusief de verstrekking van de insectenlarven werd per hok bepaald (verstrekte voer minus overgebleven voer/BSF larven). Lichaamsgewicht toename (BWG), gemiddelde dagelijkse gewichtstoename (ADG), voerconversie (FCR), voeropname (FI), gemiddelde dagelijkse voeropname (ADFI) werden uit deze data berekend per hok voor de volgende perioden: $0-7 d, 7-$ $15 d, 15-21 d, 21-28 d, 28-35 d$, en $0-35 d$. Selectie, uitval en gezondheid werden dagelijks vastgelegd (inclusief mogelijke oorzaak van selectie, ziekte of uitval). Bij plaatsing werden alle kuikens individueel gewogen. Daarna werden alle kuikens eenmaal per week individueel gewogen op hetzelfde moment als de bepalingen voor veer- en huidschade, bevuiling en voetzoollaesies. De gedragswaarnemingen werden uitgevoerd met behulp van videobeelden, die in week 1, 3 en 5 op 4 verschillende momenten gemaakt werden: 10.00-11.00 u (vóór verstrekking van larven), 11.00-12.00 u, 12.00-13.00 u en 18.00-19.00 u. Larven werden om 11.00 u verstrekt. De analyse van de videobeelden werd op twee manieren gedaan: Scan sampling fourageer- en scharrelgedrag en sampling van de gedragingen verenpikken en agressief pikken.

Direct vanaf de start waren de kalkoenkuikens zeer geïnteresseerd in de larven en aten ze vlot op. Over de hele periode was de dagelijkse voeropname van de kalkoenen die BSF larven kregen significant hoger dan die van de controledieren, met daardoor een grotere toename van het lichaamsgewicht voor de BSF larven groepen en een hoger eindgewicht op 5 weken leeftijd (2190 vs. $2015 \mathrm{~g} ; P=0.003)$. De voerconversie van de kalkoenen die BSF larven kregen was significant lager dan die van de controledieren, vooral in de periode tot 15 dagen leeftijd.

Veer- en huidschade was erg beperkt in de eerste 3 weken, met een tendens naar minder beschadigingen in de BSF larven groepen. In week 4 en 5 was er een significant verschil in het voordeel van de BSF larven groepen.

Bevuiling van de bevedering was niet verschillend in de eerste twee weken. In de derde en $5^{\mathrm{e}}$ week hadden de controledieren schonere veren. In week 4 was er geen verschil.

De incidentie van voetzoollaesies nam toe met de leeftijd. In de eerste drie weken hadden de controledieren meer voetzoollaesies, maar daarna was er geen verschil meer. 
Dieren die BSF larven kregen, vertoonden minder fourageergedrag in de derde en vijfde week vergeleken de controledieren, terwijl er in de eerste week een tendens was voor meer fourageergedrag bij de BSF larven groepen. Voor niet-fourageer gerelateerde gedragingen waren er geen duidelijke trends.

Hoewel de verschillen klein waren, reduceerde de verstrekking van BSF larven het agressief pikken. Dit was vooral zichtbaar in de periodes van de dag, waarop geen larven verstrekt werden. In de periodes dat larven verstrekt werden, werd geen verhoging van agressie waargenomen als gevolg van competitie voor de larven. Met betrekking tot verenpikken werden geen duidelijke verschillen gevonden tussen de groepen.

Uit de visuele strooiselbeoordeling op 35 dagen leeftijd kwamen geen verschillen als gevolg van de voerbehandeling naar voren.

Concluderend kan gesteld worden dat het verstrekken van de BSF larven een klein voordeel opleverde, maar de problemen met beschadigend pikgedrag niet volledig konden oplossen. 


\section{Introduction}

Injurious pecking behaviour is a severe problem in laying hens and turkeys. Successful measures in laying hens to avoid damaging pecking behaviour seem to have minor effects in turkeys. This can be explained by the fact that a turkey is a different animal species with perhaps a different underlying motivation for showing injurious pecking behaviour than a laying hen. A study was performed on natural behaviour patterns and species-specific properties of turkeys (Van Niekerk \& Bracke, 2016). This study offers opportunities to deal with current problems of damaging pecking behaviour in commercial turkeys.

In commercial turkeys two periods are indicated with peaks of pecking behaviour: at 4 days of age as first wing feathers appear and from 8 weeks when turkeys start to become adult. In particular, male turkeys express damaging pecking behaviour from 8 weeks of age but even at younger ages. Several studies have shown that mortality in non-beak treated turkeys is twice as high as in beak treated turkeys, despite different measures against pecking (treated 5-8\%; non-treated: 10-16\%; Spindler et al., 2013).

Literature on pecking behaviour of turkeys is scarce. Results from studies indicate that measures which are very effective in reducing damaging pecking behaviour in laying hens, such as supplementations in the litter or distraction tools, have insufficient effect in turkeys (Veldkamp, 2012). Nutrition may also affect pecking behaviour, however it is not clear how to avoid damaging pecking behaviour in turkeys by nutritional adjustments.

Comparing the behaviour of wild turkeys and commercial turkeys result in a number of remarkable issues (Van Niekerk \& Bracke, 2016):

- Wild turkeys grow up with insects during the first two weeks of their life. The insects are caught by the turkeys themselves. Commercial turkeys often experience problems with localisation of feed and water. It is not clear to what extent the lack of the turkey breeder and/or the taste and/or liveliness of the diet affects the development of the turkey poult and the start of damaging pecking behaviour.

- Scratching the ground or ranging of wild turkeys and wild chickens in nature is similar. In commercial husbandry however chickens still show the scratching behaviour but turkeys show this scratching behaviour much less. It seems that during early development of explorative and/or scratching behaviour in commercial turkeys something is failing.

An important question is: What is the ideal early rearing for commercial turkeys to stimulate the development of natural (scratching) behaviour and subsequently direct their pecking behaviour towards the ground? The feeding form of wild turkeys during the first two weeks of life (live insects) is in large contrast with the current physical form (crumbs or small pellets) of diets fed to day-old turkey poults. A more lively diet may improve natural (scratching, ranging, foraging) behaviour in turkey poults.

\subsection{Aim of the project}

The project had the following aims:

3. Stimulate the scratching, foraging, ranging behaviour of young turkeys poults in order to avoid damaging pecking behaviour.

4. Supplement the diets with live insects (animal proteins) to avoid damaging pecking behaviour in non-beak treated turkeys. 


\section{Materials and method}

\section{$2.1 \quad$ Animals}

In this experiment only male turkeys (Hybrid Converter) were used. In general, it can be stated that rearing male turkeys is more difficult than female turkeys as males usually perform more and more severe injurious pecking than females. In total 300 day-old turkey poults were ordered. The beaks of all turkeys were intact, thus NOT treated by infrared.

\subsection{Accommodation}

The research was carried out in one room of a research unit (DB, Lelystad, room 161.07). In this room 14 floor pens were placed. In each pen $\left(1.5 \mathrm{~m}^{2}\right), 20$ day-old turkey poults (males) were placed. The birds were kept until 35 days of age.

There were 2 treatments with 7 replicates per treatment:

CONTROL: standard feed

- $\quad$ INSECTS: each day the birds got a bucket with live insect larvae (Black Soldier Fly, BSF). The amount of insect larvae was calculated to be $10 \%$ of the expected daily feed intake. Additionally the birds got a modified feed, in which the nutritional composition was adapted so that both control and insect groups got the same daily nutrients, based on a similar expected feed intake.

\section{$2.3 \quad$ Feed}

During the first days of life the turkey poults not only had the availability of a feed trough, but also a feeding plate on which feed was provided. For the BSF groups the larvae were presented on the same feeding plate until 18 days of age. At day 18 the feeding plates were removed from the pens and from this age feed and BSF larvae were provided in the feed trough.

In each pen of the BSF group insect larvae were provided each day. The amount of larvae was determined daily based on $10 \%$ of the expected feed intake. The additional feed and water was provided ad lib. The formulation of the diets in feeding phase I and II (Annex 1 and 2, respectively) was according to the recommendations of Hendrix Genetics for the Hybrid Converter, based on the nutrient requirements of this commercial turkey strain. The composition of the turkey premix is presented in Annex 3. The diet for the birds that also received BSF larvae was formulated in a way that the calculated daily nutrient intake of both the control and the insect groups were similar, based on the expected feed intake. In fact, the feed for the birds that also received BSF larvae was formulated by inclusion of $10 \%$ of Black Soldier Fly (BSF) larvae with a known nutrient composition in the ration. The chemical composition of directly frozen Black Soldier Fly is presented in the certificate of analysis in Annex 4 . So always $10 \%$ of the daily feed intake existed of live BSF larvae (based on fresh weight).

In feeding phase I (1-21 days of age) a medium crumb ( $2.5 \mathrm{~mm}$ diameter and $2.5 \mathrm{~mm}$ length) and in feeding phase II (21-35 days of age) a coarse crumb ( $3 \mathrm{~mm}$ diameter and $5 \mathrm{~mm}$ length) was fed. Live BSF larvae were obtained from Protix twice per week and stored in a dark cool room. Portions of BSF larvae to be supplied in each pen were weighed and subsequently provided on the feeding plate. 


\section{$2.4 \quad$ Management}

\subsubsection{Water}

In the pens a bell drinker was available during the first few days. Each pen also had a small bell drinker. This small bell drinker was removed on day 3 .

\subsubsection{Lighting}

High frequency dimmable lights were used. At the day of placement in the house, 1 hour dark was given from 23.00 until $00.00 \mathrm{~h}$. Thereafter the dark period was increased with $1 \mathrm{~h}$ per day until a light schedule of $16 \mathrm{~L}: 8 \mathrm{D}$ was reached at day 8 . The dark period was from $23.00-07.00 \mathrm{~h}$ and the light period from $07.00-23.00 \mathrm{~h}$ (Annex 5). At the start of the trial the aim was 100 lux at bird eye level, but this could not be achieved (the average light intensity in week 1 was 78 Lux). Therefore the light sources were changed in week 2 and remained on that level until the end of the trial. Light intensity was kept equal in all pens.

\subsubsection{Climate}

The temperature in the house was set according to the schedule in Annex 6. Gradually the temperature was decreased by hand and not automatically, based on the behaviour of the turkey poults.

\subsubsection{Vaccinations}

The turkey poults were vaccinated twice:

\begin{tabular}{llll}
\hline Age (days) & Disease & Vaccin & Method \\
\hline 1 & TRT & Nobilis TRT & Spray (1 dosis) \\
14 & NDV & Nobilis ND Clone 30 & Spray (1 dosis) \\
\hline
\end{tabular}

\subsection{Observation}

\subsubsection{Feed}

The feeds (phase I and phase II of the control feed as well as of the experimental feed) were analysed at the start of the experiment on dry matter, crude protein, crude fat, crude fibre, ash, Ca, P and amino acids. The analysis of the BSF larvae was provided by the company that produced them.

\subsubsection{Growth performance}

Body weight (BW) of turkeys per pen was determined at $0,7,15,21,28$ and 35 days of age on an individual basis. Feed use and the amount of BSF larvae were determined per pen (provided feed/larvae minus remaining feed/larvae). Body weight gain (BWG), average daily gain (ADG), feed conversion ratio (FCR), feed intake (FI), average daily feed intake (ADFI) were calculated on a pen basis from these data for the following periods: $0-7 d, 7-15 d, 15-21 d, 21-28 d, 28-35 d$, and 0 - 35d. BWG = BW end period - BW start period; ADG = BWG / length period; FCR = (Total FI / (Total BW end period - total BW start period + total BW of dead or culled birds)); FI = FCR $\times$ BWG; ADFI = FI / length period.

Twice daily, in the morning and the afternoon, animals and housing facilities were inspected by animal care takers, thereby checking the general health status, feed and water supply as well as lighting, temperature and ventilation, and recognizing unexpected events. All incidences were recorded in the Digital Study Log Book. 
If an animal was in poor condition, health status was observed more frequently. Turkey poults suffering pain or distress were selected, culled and the cause of the death or distress was recorded. In all cases of mortality, birds were weighed and date of death was recorded.

\subsubsection{Exterior}

At placement all chicks were weighed individually. Thereafter all birds were weighed individually once a week and at the same time scored for feather and skin damage.

The following scores were used to score feather and skin damage:

\begin{tabular}{|l|l|}
\hline $\mathbf{0}$ & no naked spots, no signs of pecking \\
\hline $\mathbf{1}$ & small $\left(<0,5 \mathrm{~cm}^{2}\right)$ naked spots on wings, tail or neck \\
\hline $\mathbf{2}$ & larger $\left(>0,5 \mathrm{~cm}^{2}\right)$ naked spots on wings, tail or neck or minor tissue damage due to pecking \\
\hline $\mathbf{3}$ & extensive naked areas on wings, tail or neck or serious tissue damage due to pecking \\
\hline $\mathbf{4}$ & very large naked areas; severe tissue damage \\
\hline
\end{tabular}

(scoring method derived from Grigor et al., 1995)

Every week the turkeys were also scored on the following exterior issues:

Cleanliness ( 0 =clean; 1 =slightly ; 2 =slightly dirty; 3 =moderate to severely dirty)

Foot pad dermatitis (FPD) score (scale $0 \mathrm{t} / \mathrm{m} 4$ according to the method of Hocking et al., 2008)

$0 \quad$ No external signs of FPD. The skin of the foot pad feels soft to the touch and no swelling or necrosis is evident.

1 The pad feels harder and denser than a non-affected foot. The central part of the pad is raised, reticulate scales are separated and small black necrotic areas may be present.

$2 \quad$ Marked swelling of the foot pad. Reticulate scales are black, forming scale shaped necrotic areas. The scales around the outside of the black areas may have turned white. The area of necrosis is less than one quarter of the total area of the foot pad.

3 Swelling is evident and the total foot pad size is enlarged. Reticulate scales are pronounced, increased in number and separated from each other. The amount of necrosis extends to one half of the foot pad.

4 As score 3, but with more than half the foot pad covered by necrotic cells.

These scorings were done on all birds during weighing, so that they only had to be handled once.

\subsubsection{Behavioural observations}

The behavioural observations were carried out using video recordings. Per day recordings were made of 4 pens pens ( 2 with BSF larvae and 2 control; the last day of the week 2 pens, 1 with and 1 without BSF larvae), so that after 4 days all pens were recorded during one day. The video recordings were done in the weeks 1,3 en 5 , so that one recording day per week per pen was available.

BSF larvae were provided between 11.00 and $11.15 \mathrm{~h}$.

The video recordings were made in 4 different periods of the day:

Before: $10.00-11.00 \mathrm{~h}$

During: $11.00-12.00 \mathrm{~h}$

After: $12.00-13.00 \mathrm{~h}$

PM: $18.00-19.00 \mathrm{~h}$

The time frame 18.00-19.00 $\mathrm{h}$ was chosen as this was not linked to any provided feeding or other activities in the house.

In week 3 and 5 recordings of 4 hours per day are analysed, in week 1 only 3 hours were analysed, the period $12.00-13.00$ was skipped. 
The analysis of the video recordings was done in 2 different ways:

Scan sampling of activity and foraging behaviour:

For each recording every 5 minutes the number of chicks was counted according to the ethogram below:

Table 1 Ethogram of activity and foraging behaviour

\begin{tabular}{ll}
\hline Behaviour & Description \\
\hline FORAGING & Pecking in/at the feed trough (other than insect tray) \\
Insect pecking & Pecking in/at the insect tray \\
Drinking & Pecking in/at the nipple drinker/bell drinker \\
Ground pecking & Pecking at the ground \\
Ground scratching & Scratching over the ground \\
Object pecking & Pecking at objects other than feed, water or ground \\
ACTIVITY & Walking or running \\
Walking & Standing without activity \\
Standing & Sitting or lying down without activity \\
Resting & \\
OTHER & Aggressive to conspecific: jumping up, chasing, etc. \\
Fighting & With feathers wide and high neck/head walking/standing \\
Trotting & \\
Other & \\
\hline
\end{tabular}

Behaviour sampling of feather pecking and aggressive pecking:

By means of behaviour sampling (sampling all occurrences of some behaviours) the video recordings were analysed again. Every bout of feather pecking or aggressive pecking was recorded. Also the body part at which the pecking behaviour was directed was recorded. A bout ended if during 5 seconds no pecking was seen, or if the pecking was redirected towards another body part. For this the ethogram in Table 2 was used. The response of the receiver was not recorded.

Table 2 Ethogram of feather pecking and aggressive pecking

\begin{tabular}{|c|c|c|}
\hline Behaviour & Bodypart & Description \\
\hline \multirow[t]{3}{*}{$\begin{array}{l}\text { Aggressive } \\
\text { pecking }\end{array}$} & Head and neck & $\begin{array}{l}\text { Bout of aggressive pecking behaviour directed to the } \\
\text { head and neck }\end{array}$ \\
\hline & Back and tail base & $\begin{array}{l}\text { Bout of aggressive pecking behaviour directed to the } \\
\text { back and tail base }\end{array}$ \\
\hline & Wings & $\begin{array}{l}\text { Bout of aggressive pecking behaviour directed to the } \\
\text { wings }\end{array}$ \\
\hline \multirow[t]{6}{*}{ Feather pecking } & Head and neck & $\begin{array}{l}\text { Bout of feather pecking or -pulling directed to the } \\
\text { head and neck }\end{array}$ \\
\hline & Back and tail base & $\begin{array}{l}\text { Bout of feather pecking or -pulling directed to the } \\
\text { back and tail base }\end{array}$ \\
\hline & Tail & Bout of feather pecking or -pulling directed to the tail \\
\hline & Cloaca & $\begin{array}{l}\text { Bout of feather pecking or -pulling directed to the } \\
\text { cloaca }\end{array}$ \\
\hline & Wings & $\begin{array}{l}\text { Bout of feather pecking or -pulling directed to the } \\
\text { wings }\end{array}$ \\
\hline & Legs & Bout of feather pecking or -pulling directed to the legs \\
\hline
\end{tabular}

\subsubsection{Litter quality}

Visual litter quality was determined at $35 \mathrm{~d}$ of age by an assessor on a 5-point scale (Table 3 ). Scores for friability of the litter layer varied from score $1=$ friable to score $5=$ complete caked litter, no 
caked litter particles. Scores for wetness of the litter layer ranged from score 1 = very dry litter to score 5 = wet litter, total area, water is appearing by pressure on the litter.

Table 3 Description of the visual litter scores for friability and wetness.

\begin{tabular}{lll}
\hline Score & Friability description & Wetness description \\
\hline 1 & Friable litter, no caked areas & Very dry litter (only observed at start) \\
2 & $25 \%$ area caked & Almost dry litter, light coloured, no ridges beneath drinking line \\
3 & $50 \%$ area caked & Wet litter, dark coloured. Ridges occur beneath the drinking line \\
4 & $75 \%$ area caked & Wet litter, dark coloured. Litter can be pressed into ball-shape \\
5 & Completely caked & Wet litter, total area, water is appearing by pressure on the \\
& & litter \\
\hline
\end{tabular}

\subsection{Statistical analysis}

The averages of all parameters were analysed using the statistical program Genstat. Behaviour is analysed with week and hour as blocks. 


\section{Results and Discussion}

\section{$3.1 \quad$ General}

The average body weight of the day-old turkeys was 61 gram. Feed intake and body weight gain of the turkeys in the experiment (Figure 1) was according to Hybrid Converter Commercial Males objectives (Hendrix Genetics, 2017). Final body weight at $35 \mathrm{~d}$ of age of the turkeys in the experiment was $2102 \mathrm{~g}$ whereas body weight in the Hybrid Converter Commercial Males objectives was $2060 \mathrm{~g}$ at $35 \mathrm{~d}$ of age. Mean daily feed intake, daily body weight gain and feed conversion ratio was $73 \mathrm{~g} / \mathrm{d}, 58$ $\mathrm{g} / \mathrm{d}$ and 1.26 of turkeys in the experiment and $73 \mathrm{~g} / \mathrm{d}, 57 \mathrm{~g} / \mathrm{d}$ and 1.25 , respectively according to breeder standards over the period 0 to $35 \mathrm{~d}$ of age.

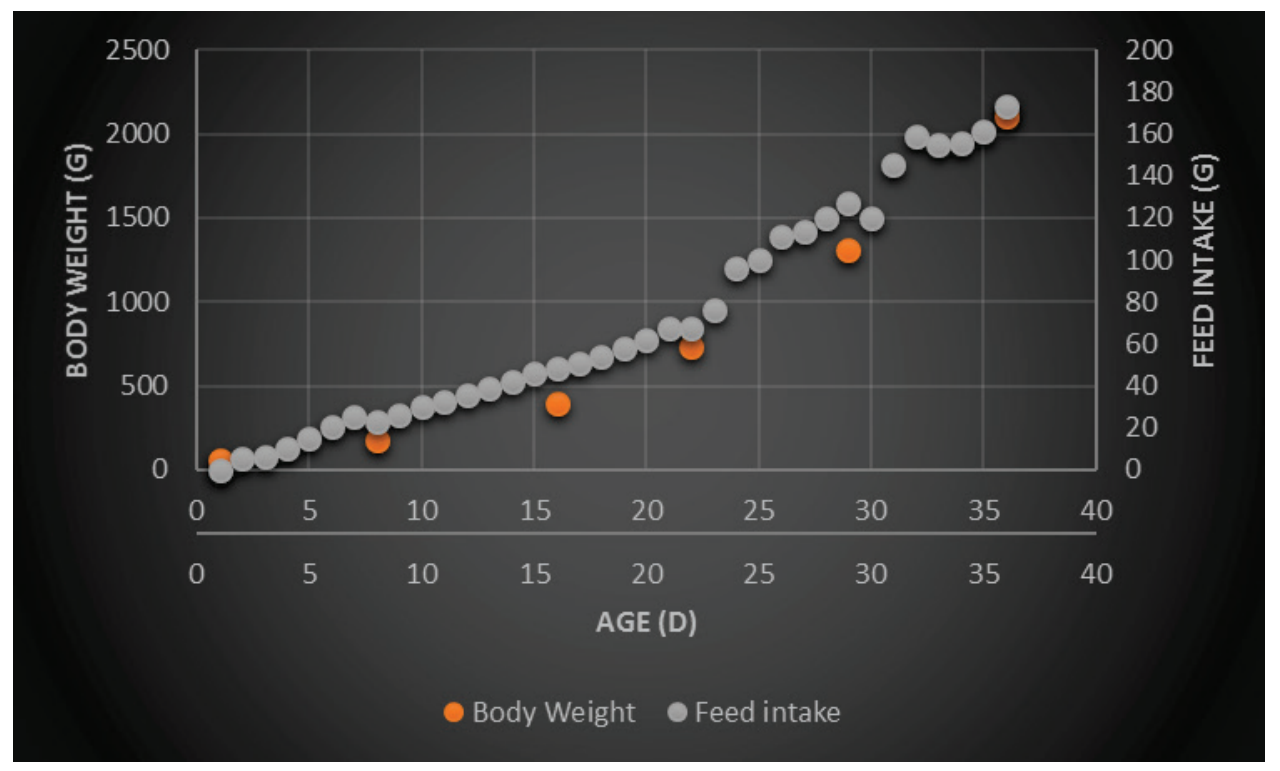

Figure 1 Feed intake and body weight gain of turkeys in the experiment from 0 to $35 d$ of age

Average mortality during the experimental period ( 0 - 35 days of age) was $6.1 \%$ and no specific cause of mortality was observed. The trial was performed with only males and it is well known that the mortality rate for males is higher than for females. The mortality rate was according to mortality rates in practice.

\subsection{Diet analyses}

In Appendix 1 and 2 the calculated and analysed nutrient compositions of the standard and experimental diets in feeding phase I and II are presented, respectively. The diets were formulated iso-nitrogenous and iso-caloric as $10 \%$ BSF larvae are included in the ration. In Appendix 1 and 2 the calculated and analysed nutrient compositions are presented without inclusion of BSF larvae because these are the diets as produced by the experimental feed company.

The analysed crude protein (CP) content of diets in phase I and II in general met the calculated contents. On average the analysed CP contents of the phase I diet were 7.8 and $2.9 \mathrm{~g} / \mathrm{kg}$ lower than the calculated CP contents for the standard diet and experimental diet, respectively. The analysed CP contents of the phase II diet were $4.2 \mathrm{~g} / \mathrm{kg}$ lower and $1.5 \mathrm{~g} / \mathrm{kg}$ higher than the calculated CP contents for the control diet and the insect diet, respectively. These deviations are acceptable. For the standard diet and experimental diet, respectively, the analysed crude fat contents were 1.5 and $3.6 \mathrm{~g} / \mathrm{kg} \mathrm{higher}$ than calculated crude fat contents in the diets. Analysed calcium contents were lower than calculated calcium contents in the diets and analysed phosphorus contents were in agreement with the calculated 
phosphorus contents in the diets. The sum of analysed amino acid contents in the diets were in agreement with the sum of calculated amino acid contents in the diets. For the standard diet and experimental diet, respectively, the analysed lysine contents were 0.75 and $1.15 \mathrm{~g} / \mathrm{kg}$ lower than calculated lysine contents in the diets. The lower analysed lysine contents in the diets could have had an adverse effect on growth performance but in general, as described in paragraph 3.4, the level of performance was comparable with Hybrid Converter Commercial Males objectives.

\subsection{Supply and consumption of BSF larvae}

In the BSF larvae fed turkeys it was aimed to supply $10 \%$ of the daily feed intake in the form of live BSF larvae. Every day the feed intake of the turkeys was recorded and the amount of BSF larvae to be fed was calculated as $10 \%$ from this feed intake. Turkeys were very eager to eat the BSF larvae. Consumption of BSF larvae started immediately after provision. All provided BSF larvae were consumed between one and two minutes after provision and no left-overs of BSF larvae were observed. The feed was supplied ad libitum in both the control groups and in the BSF larvae fed groups. In Figure 2, 3 and 4 the realised daily intake of feed and BSF larvae of turkeys in the BSF Larvae fed groups and the Control fed groups is presented.

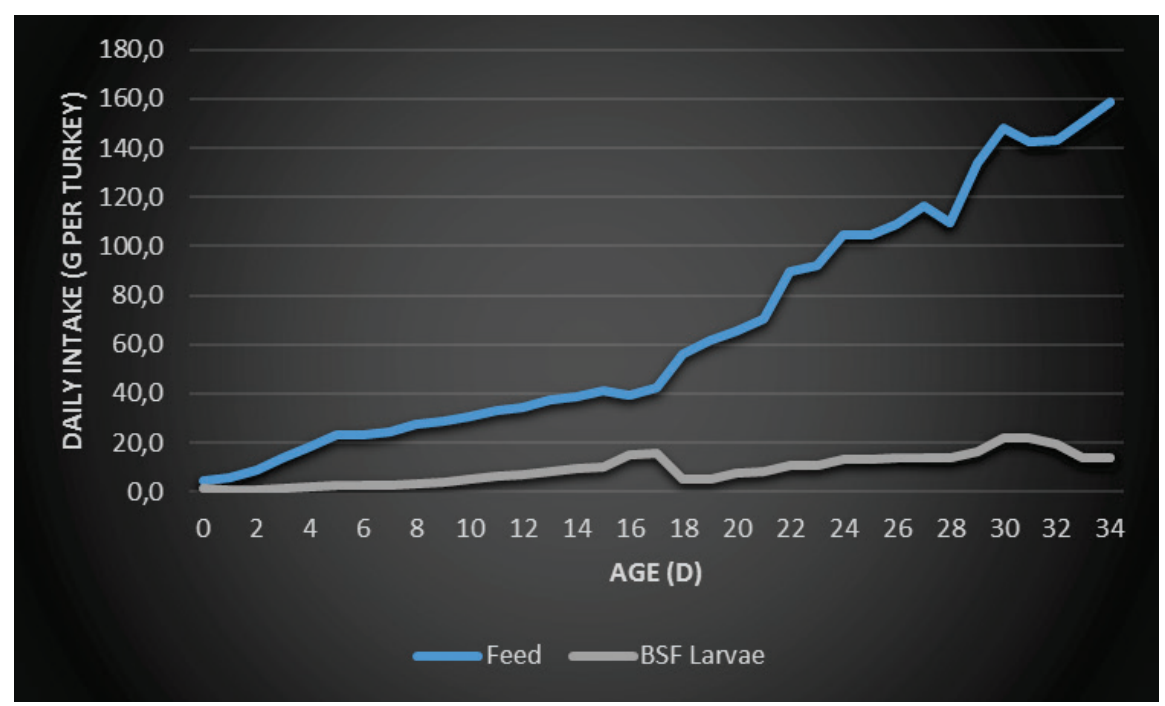

Figure 2 Daily intake of feed and BSF Larvae in BSF Larvae fed turkeys

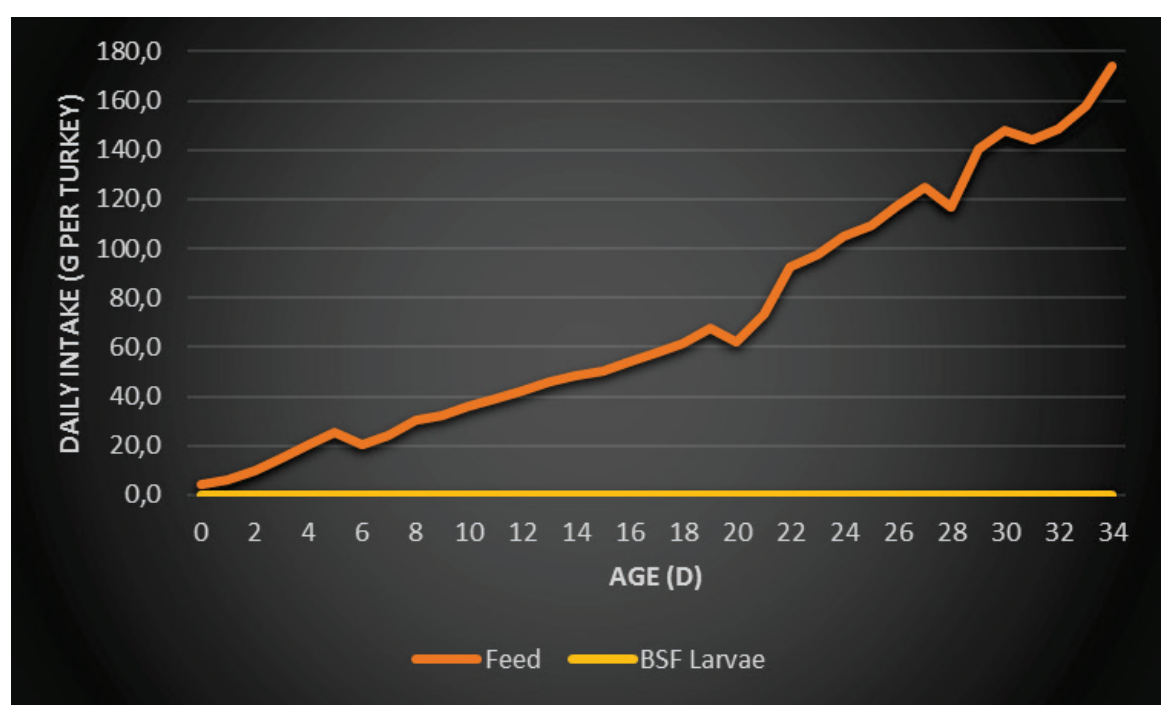

Figure 3 Daily intake of feed and BSF Larvae in Control fed turkeys 


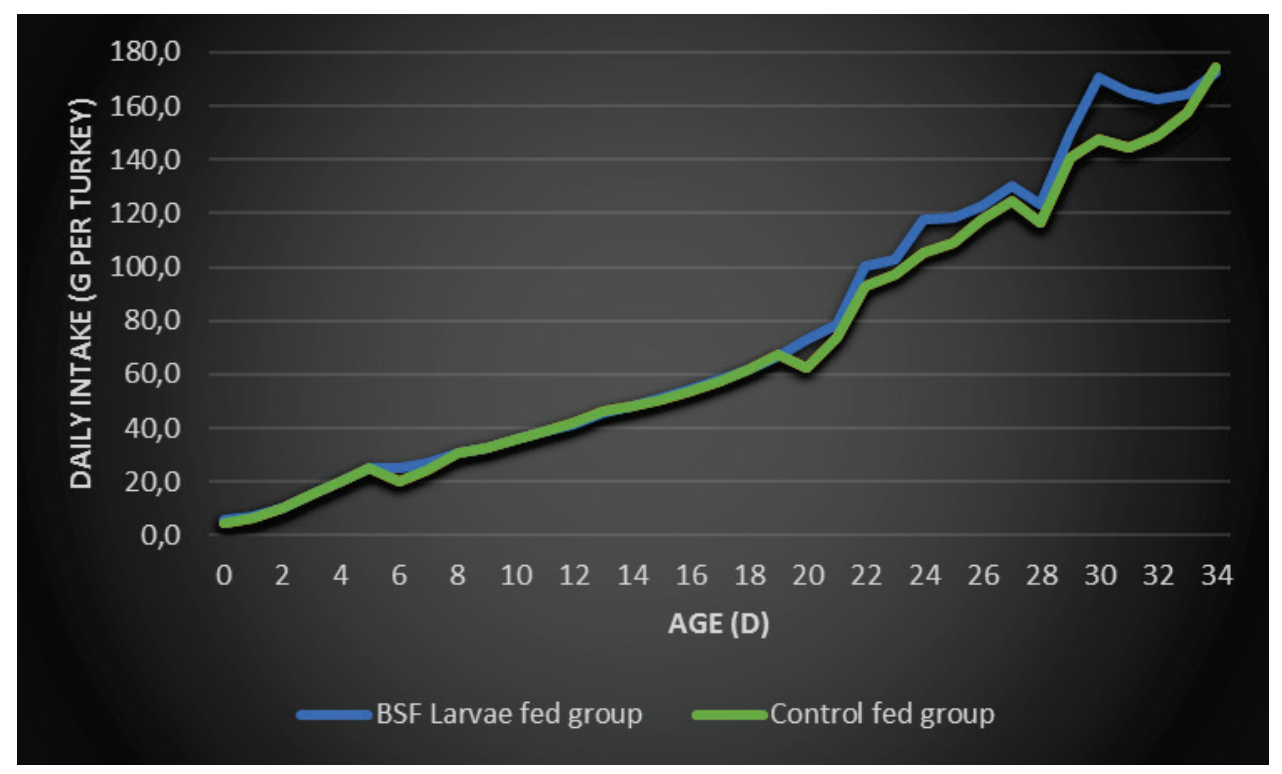

Figure 4 Daily combined intake of feed and BSF Larvae in BSF Larvae fed turkeys and Control fed turkeys

In the period 0 to 35 days of age the total feed intake of BSF Larvae fed turkeys was $2332 \mathrm{~g}$ and the total BSF Larvae intake was $321 \mathrm{~g}$. The combined total intake of feed and BSF Larvae of BSF Larvae fed turkeys was $2653 \mathrm{~g}$. Total feed intake of Control fed turkeys was $2504 \mathrm{~g}$.

It was aimed to feed the turkeys $10 \%$ BSF Larvae of the total daily feed intake. In reality $12.1 \%$ BSF Larvae of the total daily feed intake was fed to the turkeys. The crude protein content in the BSF Larvae was lower than the crude protein content in the diet so a higher inclusion of BSF Larvae in the daily ration resulted in a lower total dietary crude protein content. The crude fat content in the BSF Larvae was higher than the crude fat content in the diet so a higher inclusion of BSF Larvae in the daily ration resulted in a higher total dietary crude fat content.

\subsection{Growth performance}

This paragraph describes the growth performance results per week and the overall experimental period (Table 4).

Overall, daily feed intake of turkeys fed BSF larvae was significantly higher than daily feed intake of Control fed turkeys (76 vs. $71 \mathrm{~g} / \mathrm{d} ; P=0.015$ ). Daily body weight gain of turkeys fed BSF larvae was significantly higher than daily body weight gain of Control fed turkeys (61 vs. $56 \mathrm{~g} / \mathrm{d} ; P=0.003$ ). Feed conversion ratio of turkeys fed BSF larvae was significantly lower than feed conversion ratio of Control fed turkeys (1.25 vs. $1.27 ; P=0.038$ ). As a result of the higher body weight gain the final body weight of the BSF larvae fed turkeys was significantly higher than the body weight of Control fed turkeys (2190 vs. $2015 \mathrm{~g} ; P=0.003$ ). The positive effect of $12 \%$ BSF larvae supplementation on feed conversion ratio was most pronounced in the period until 15 days of age. 
Table 4 Growth performance of BSF Larvae fed turkeys and Control fed turkeys from 0 to 35 days of age

\begin{tabular}{|c|c|c|c|c|}
\hline & & Control & Lsd & p-value \\
\hline & fed turkeys & fed turkeys & & \\
\hline \multicolumn{5}{|l|}{$0-7$ days of age } \\
\hline daily feed intake & $16^{a}$ & $15^{b}$ & 0.6 & 0.001 \\
\hline daily body weight gain & $17^{a}$ & $15^{\mathrm{b}}$ & 0.7 & $<0.001$ \\
\hline FCR & 0.93 & 0.98 & 0.051 & 0.082 \\
\hline \multicolumn{5}{|l|}{ 7-15 days of age } \\
\hline daily feed intake & 32 & 32 & 1.3 & 0.684 \\
\hline daily body weight gain & $30^{\mathrm{a}}$ & $27^{b}$ & 1.9 & 0.002 \\
\hline FCR & $1.06^{\mathrm{b}}$ & $1.19^{a}$ & 0.093 & 0.010 \\
\hline \multicolumn{5}{|l|}{ 15-21 days of age } \\
\hline daily feed intake & 67 & 64 & 5.5 & 0.378 \\
\hline daily body weight gain & $59^{a}$ & $54^{b}$ & 3.0 & 0.007 \\
\hline FCR & 1.14 & 1.19 & 0.079 & 0.187 \\
\hline \multicolumn{5}{|l|}{ 21-28 days of age } \\
\hline daily feed intake & $113^{a}$ & $102^{\mathrm{b}}$ & 7.3 & 0.009 \\
\hline daily body weight gain & 85 & 79 & 6.5 & 0.062 \\
\hline FCR & 1.33 & 1.30 & 0.039 & 0.132 \\
\hline \multicolumn{5}{|l|}{ 28-35 days of age } \\
\hline daily feed intake & $159^{a}$ & $148^{\mathrm{b}}$ & 8.4 & 0.018 \\
\hline daily body weight gain & $118^{\mathrm{a}}$ & $109^{b}$ & 5.9 & 0.005 \\
\hline FCR & 1.35 & 1.36 & 0.042 & 0.407 \\
\hline \multicolumn{5}{|l|}{$0-35$ days of age } \\
\hline daily feed intake & $76^{a}$ & $71^{\mathrm{b}}$ & 3.6 & 0.015 \\
\hline daily body weight gain & $61^{a}$ & $56^{b}$ & 2.9 & 0.003 \\
\hline FCR & $1.25^{\mathrm{b}}$ & $1.27^{\mathrm{a}}$ & 0.026 & 0.038 \\
\hline body weight $(0 \mathrm{~d})$ & 61 & 61 & 0.9 & 0.434 \\
\hline body weight (35 d) & $2190^{a}$ & $2015^{b}$ & 102.2 & 0.003 \\
\hline
\end{tabular}

Daily feed intake and daily body weight gain are in grams/day

$F C R=$ feed conversion ratio

Different letters in horizontal lines indicate significant differences $(p<0.05)$ 


\subsection{Exterior}

Feather and skin damage was very limited in the first 3 weeks, with a tendency to be lower in the insect groups. In week 4 and 5 there was a significant difference in favour of the BSF larvae groups. Cleanliness of the feathers was not different in the first 2 weeks. In the third and $5^{\text {th }}$ week the control birds had a cleaner feather cover. In the $4^{\text {th }}$ week there was no difference.

The incidence of foot pad lesions increased over age. They were more frequent in the control group in the first 3 weeks, but after that there was no difference anymore.

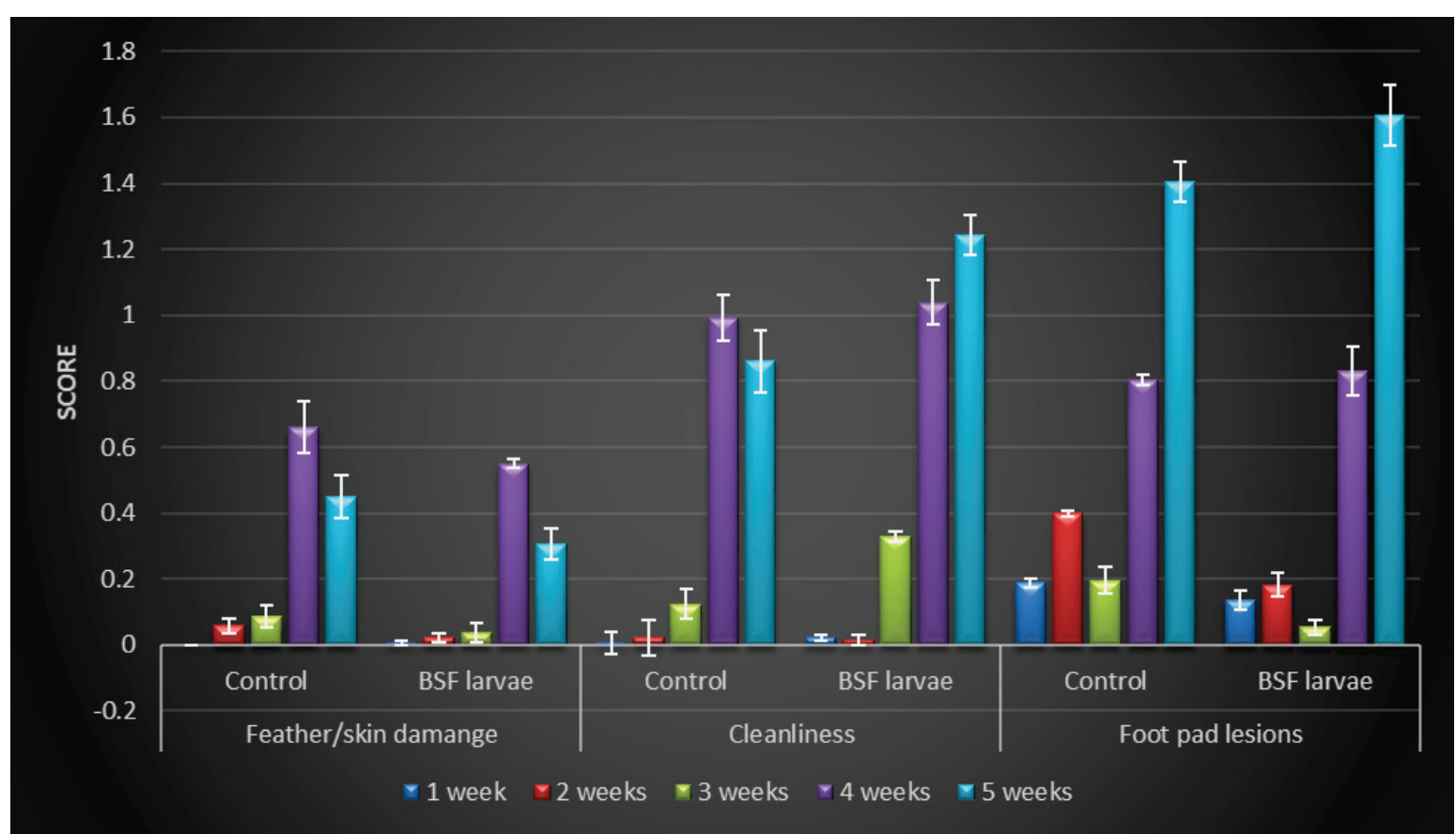

Figure 5 Feather and skin damage, cleanliness of the feathers and foot pad lesions per treatment and per week (bars indicate SEM)

\subsection{Behavioural observations}

The averages of the behavioural observations that were done in week 1, 3 and 5 in all pens are presented in the next paragraphs.

\subsubsection{Activities and scratching behaviour}

Birds from the BSF larvae groups performed more feed pecking in the first week, but less in the third and fifth week compared to the controls (figure 6). The same effect was visible for drinking and ground pecking, although for those behaviours the differences were not significant in the first week. For object pecking no statistical differences were found. If time of the day was taken into account the birds from the BSF larvae groups performed less feed pecking, drinking and ground pecking between 11.00 and $13.00 \mathrm{~h}$. compared to the control groups (figure 7). 


\section{Foraging related behaviour}

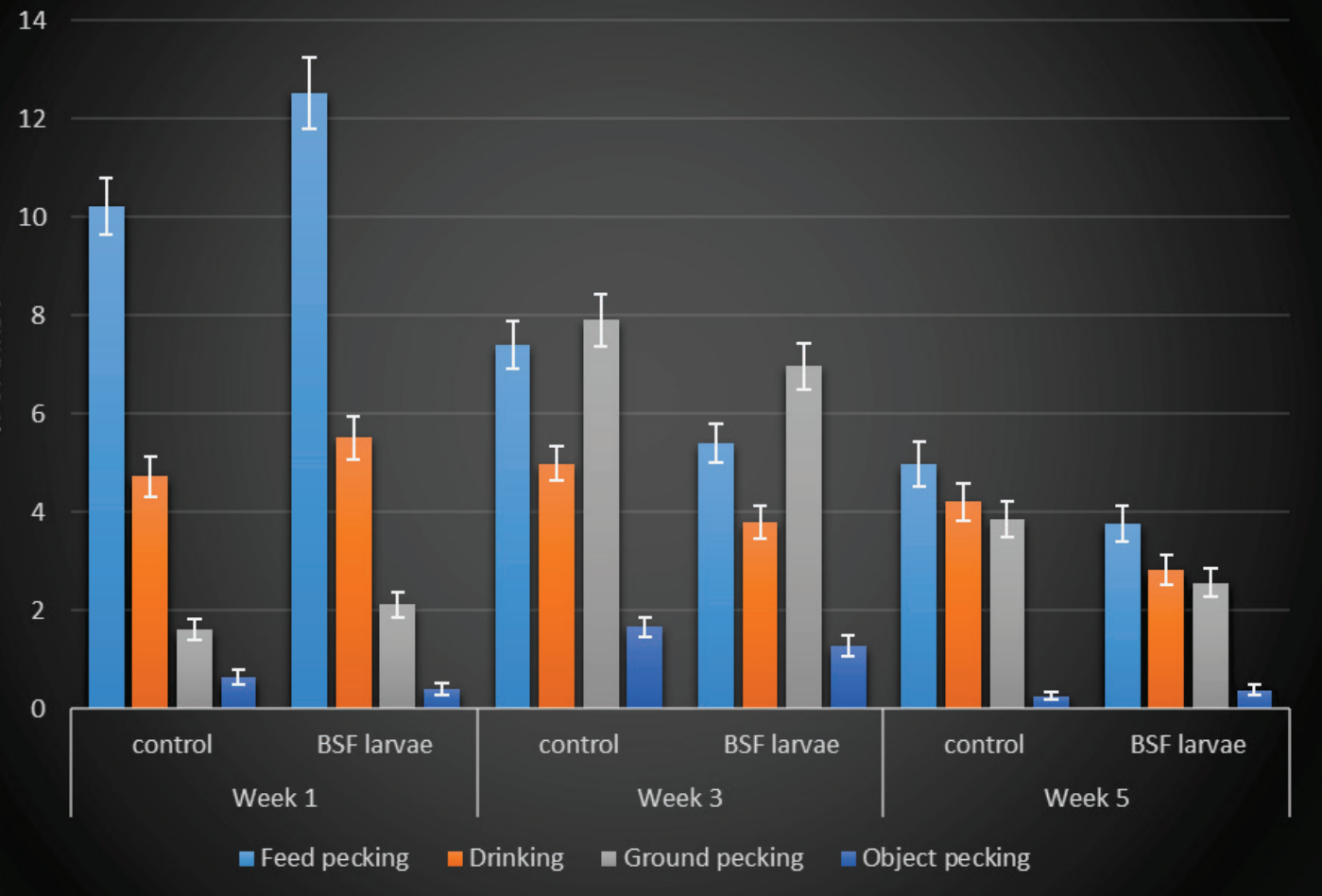

Figure $6 \quad$ Foraging related behaviour per treatment and per week

\section{Foraging related behaviour}

12

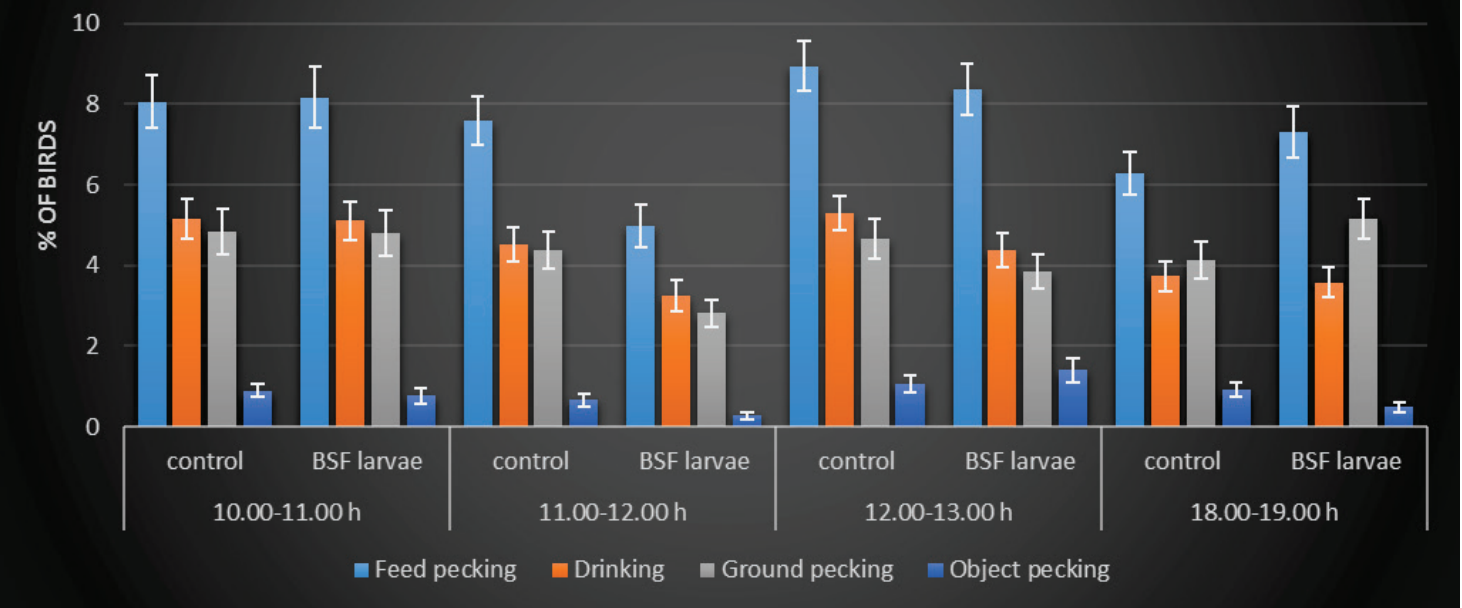

Figure $7 \quad$ Foraging related behaviour per treatment and per time frame

For activities other than foraging, mainly standing or walking, no clear trends could be observed (figure 8). Resting behaviour was seen a lot compared to the other behaviours and therefore put in a separate figure (figure 10). Birds that were fed BSF larvae did rest slightly less in the first week, but in week 3 and 5 no differences were found with the control groups. Still, if resting, standing and walking are taken into account, they all show the same tendency for more calm behaviour in week 3 and 5 for the birds fed BSF larvae. If time of the day was taken into account, there was less walking behaviour in the period $12.00-13.00 \mathrm{~h}$ for the BSF larvae groups compared to the controls (figure 9). This is in agreement with the reduced foraging behaviour shown in that period by the BSF larvae group (figure 7). Birds fed BSD larvae did rest less in the evening compared to the controls (figure 11). 


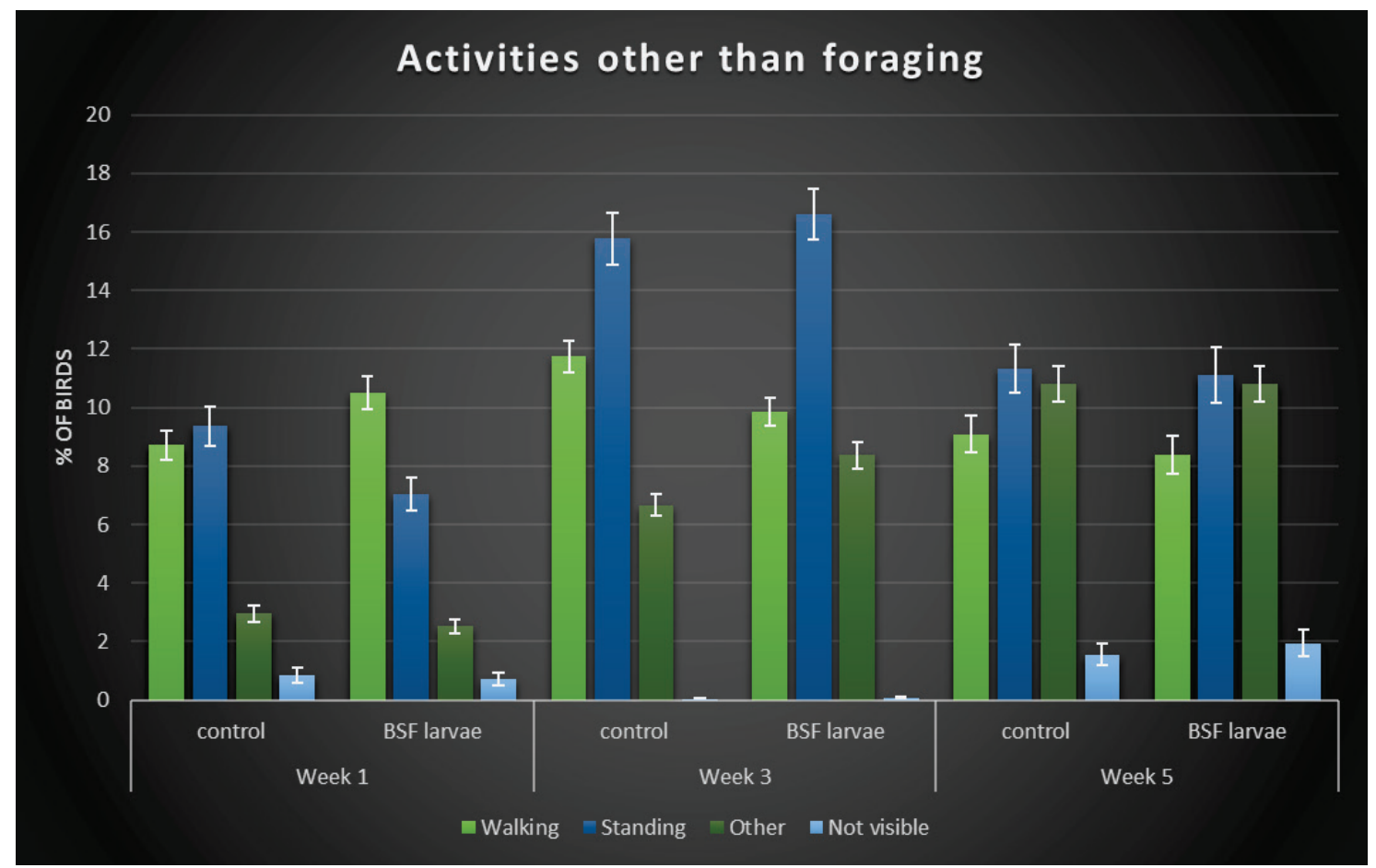

Figure $8 \quad$ Activities other than foraging related per treatment and per week

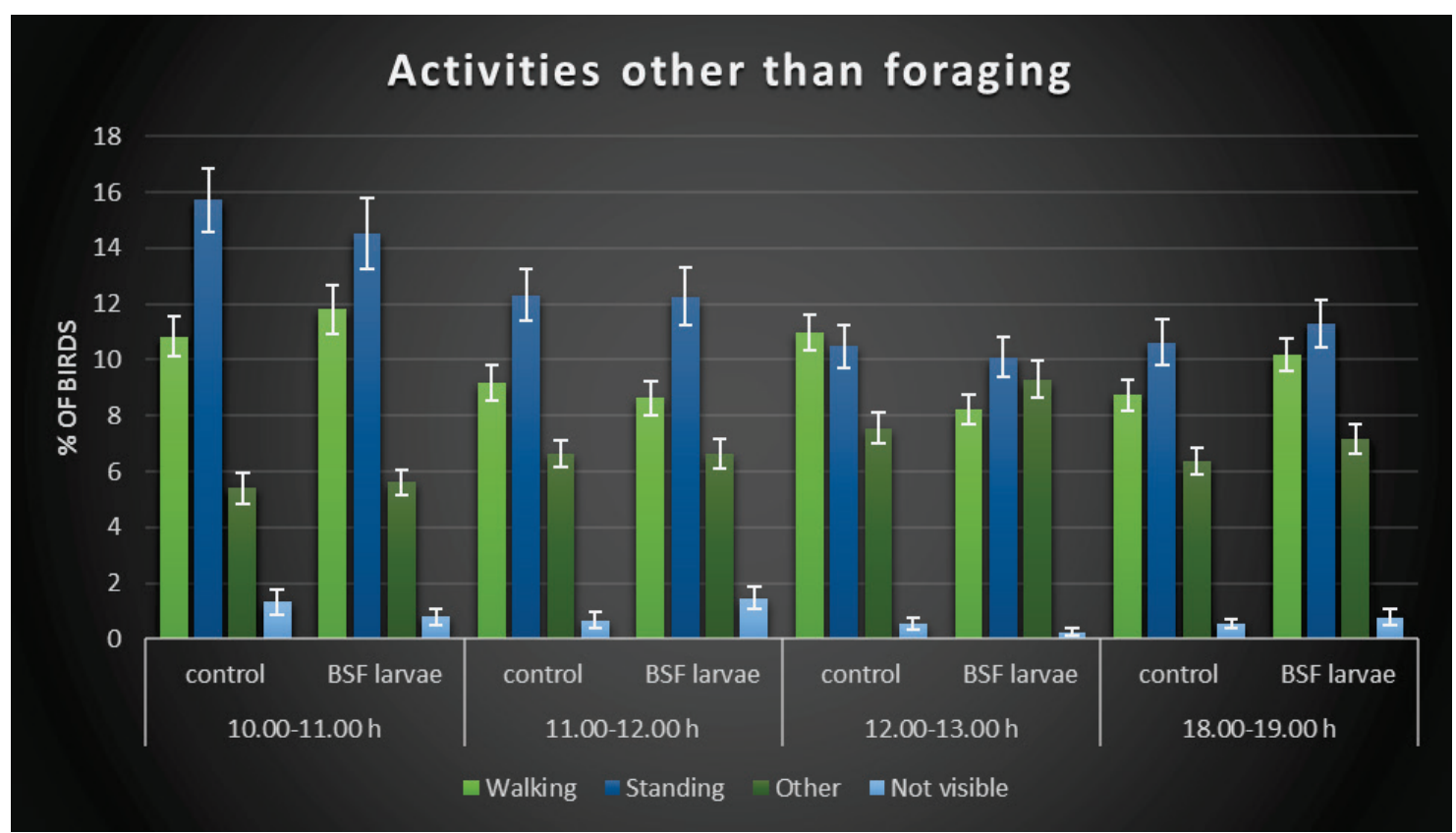

Figure 9 Activities other than foraging related per treatment and per time frame 


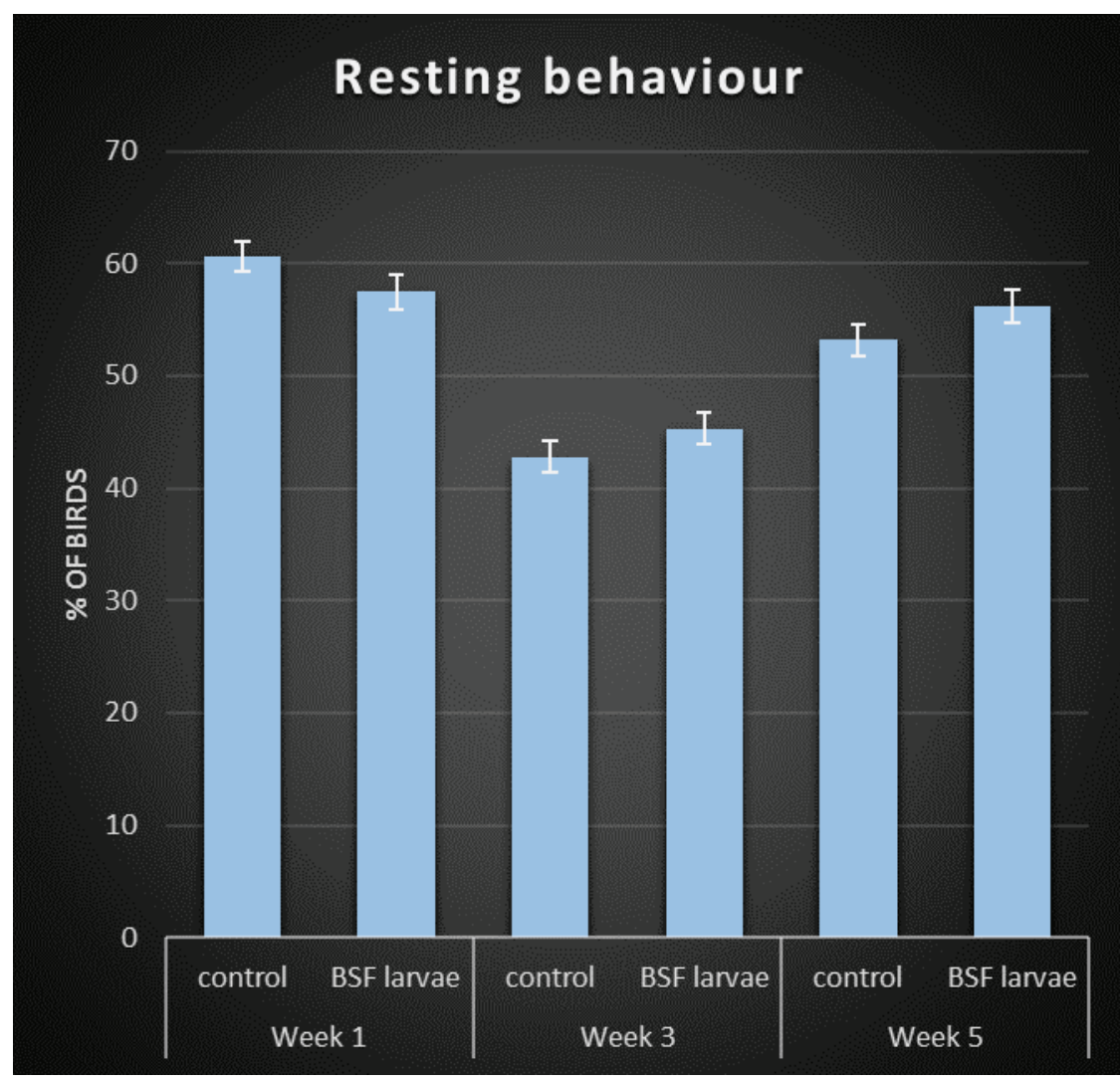

Figure 10 Resting behaviour per treatment and per week

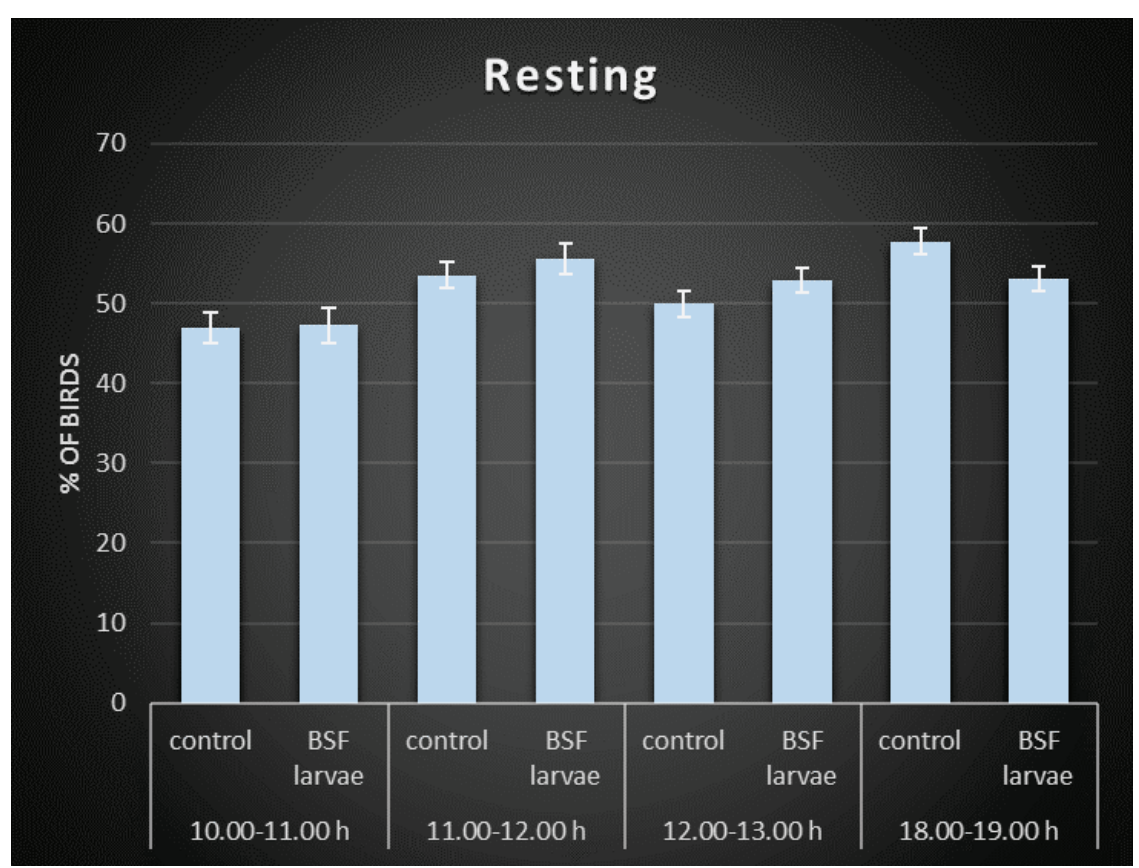

Figure 11 Resting behaviour per treatment and per time frame 
Some behaviours were very rare and therefore put in a separate figure to make them visible (figure 12). Ground scratching was one of those behaviours. It was performed more by the groups that were fed BSF larvae, as was ground pecking. Fighting was not seen in the first week. In week 3 and 5 there were no differences in fighting behaviour between control and BSF larvae fed groups. Animal pecking is either feather pecking or aggressive pecking at other birds. No differences were found in the first weeks, but in week 5 more animal pecking was observed for the groups that were fed BSF larvae. This may seem to be at odds with the results of the recordings of feather pecking and aggression (see next paragraph). However this paragraph presents the results of the scan sampling where quick behaviours like pecking can easily be missed. In the next paragraph the results are presented of the continuous observations for pecking, which is more reliable for this type of behaviour.

Trotting behaviour was observed very infrequently. It was not seen in week 1 . In week 3 the control birds did perform this a bit more (sign.), but in week 5 the frequency was equal to that in the BSF larvae groups.

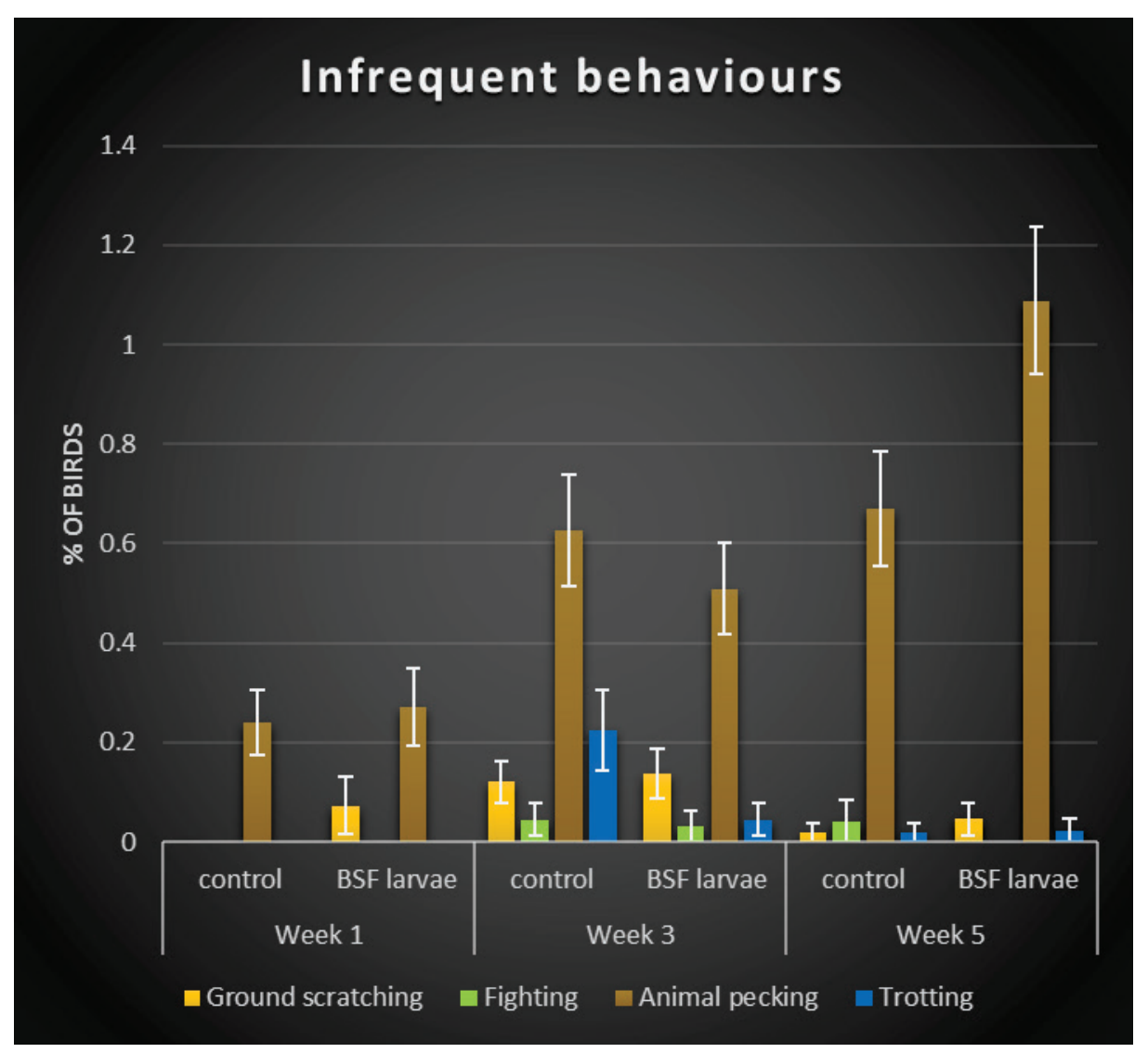

Figure 12 Infrequent behaviours per treatment and per week

If all weeks and time frames are taken together some behaviours are different between the BSF groups and the control groups (Table 5). Birds fed BSF larvae performed less drinking behaviour. As BSF larvae contain water, this is explainable. The BSF larvae group also performed less ground pecking. This is somewhat surprising, as feeding larvae was in theory a method to stimulate foraging behaviour. However, it may be possible that pecking at the larvae was itself was a rewarding type of explorative pecking thus reducing the need for (redirected) ground pecking. Finally less trotting behaviour was found in the BSF Larvae group, but as the frequency of this behaviour was very low and it was very difficult to observe on the video one can question the meaning.

No other behaviours were statistically different, meaning the differences were not present or not consistent over time. 
Table 5 Overall average activities and scratching behaviour (average \% over weeks and time of day)

\begin{tabular}{lrcc}
\hline & Control & BSFlarvae & P-value \\
\hline Feed pecking & $7.718 \pm 0.303$ & $7.174 \pm 0.323$ & 0.427 \\
Drinking & $4.668 \pm 0.219$ & $4.052 \pm 0.211$ & $\mathbf{0 . 0 5 1}$ \\
Ground scratching & $0.048 \pm 0.016$ & $0.090 \pm 0.028$ & 0.236 \\
Ground pecking & $4.494 \pm 0.245$ & $4.121 \pm 0.232$ & $\mathbf{0 . 0 8 7}$ \\
Object pecking & $0.889 \pm 0.092$ & $0.734 \pm 0.096$ & 0.155 \\
Animal pecking & $0.501 \pm 0.057$ & $0.605 \pm 0.063$ & 0.317 \\
& & & \\
Walking & $9.913 \pm 0.324$ & $9.627 \pm 0.325$ & 0.531 \\
Resting & $52.154 \pm 0.854$ & $52.360 \pm 0.892$ & 0.595 \\
Standing & $12.213 \pm 0.467$ & $11.958 \pm 0.490$ & 0.529 \\
Trotting & $0.085 \pm 0.030$ & $0.024 \pm 0.015$ & $\mathbf{0 . 0 5 0}$ \\
Fighting & $0.028 \pm 0.017$ & $0.012 \pm 0.012$ & 0.410 \\
Other & $6.519 \pm 0.260$ & $7.236 \pm 0.283$ & 0.167 \\
Not visible & $0.765 \pm 0.144$ & $0.827 \pm 0.153$ & 0.759 \\
\hline
\end{tabular}

In conclusion it can be stated that birds fed BSF larvae performed less foraging related behaviour in the third and fifth week compared to the controls, whereas in the first week there was a tendency for more foraging related behaviour for the BSF larvae groups. For activities other than foraging no clear trends could be observed.

\subsubsection{Feather pecking and aggressive pecking}

Aggressive pecking was not often performed in week 1 and 3 (figure 13), which is in line with the finding that in that period there wasn't much feather and skin damage. In week 5 aggressive pecking at the back and the tail had increased a lot in the control group, but not in the BSF larvae group, leading to a significant difference in that behaviour in week 5 .

Feather pecking occurred in all weeks and no significant differences between treatments was observed (figure 14). There was a tendency for more feather pecking between 18.00-19.00 $\mathrm{h}$ compared to the periods $10.00-11.00 \mathrm{~h}$ and $11.00-12.00 \mathrm{~h}$, but this was not significantly different. 


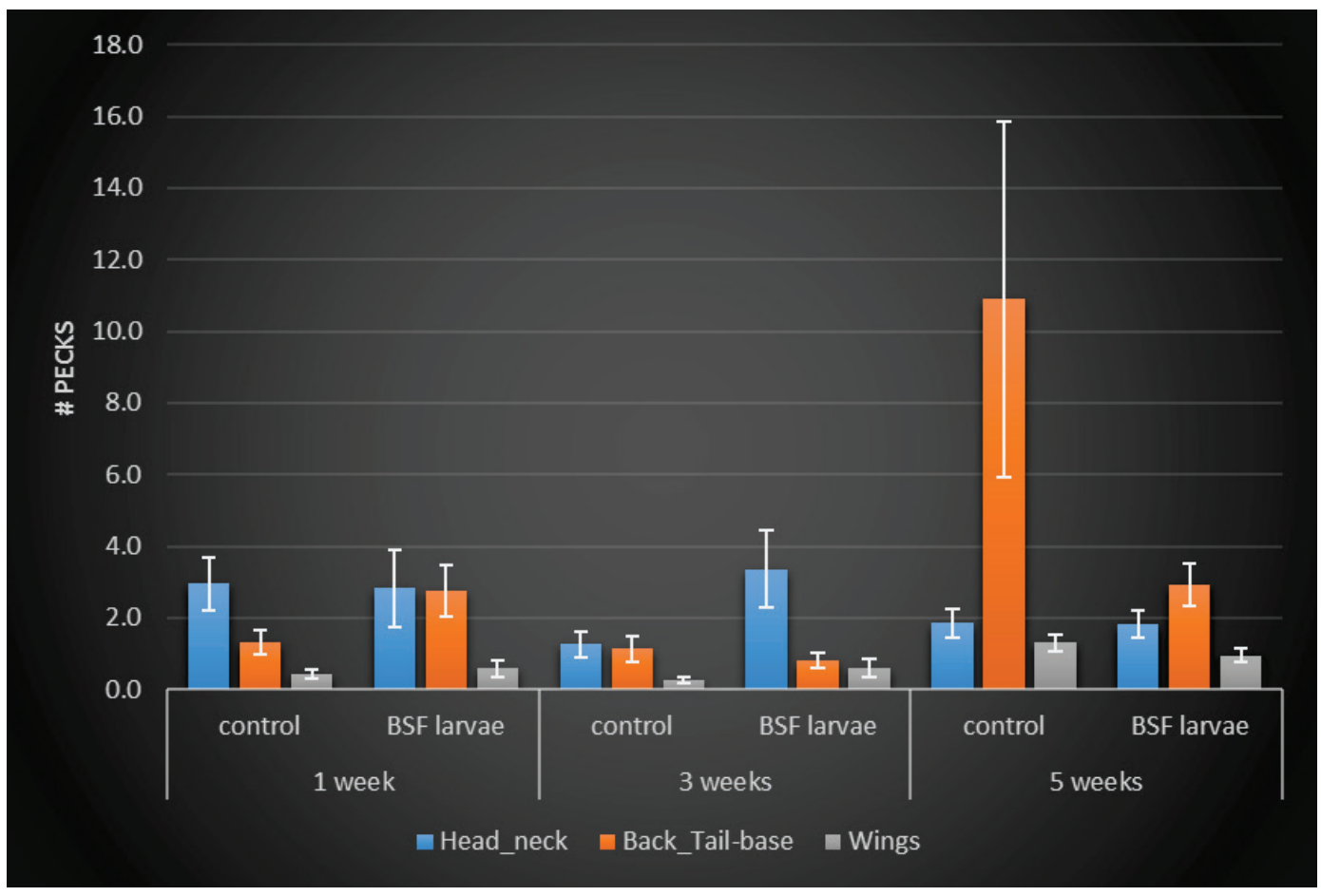

Figure 13 Aggressive pecking directed towards Head/neck, Back/tail-base and Wings per treatment and per week

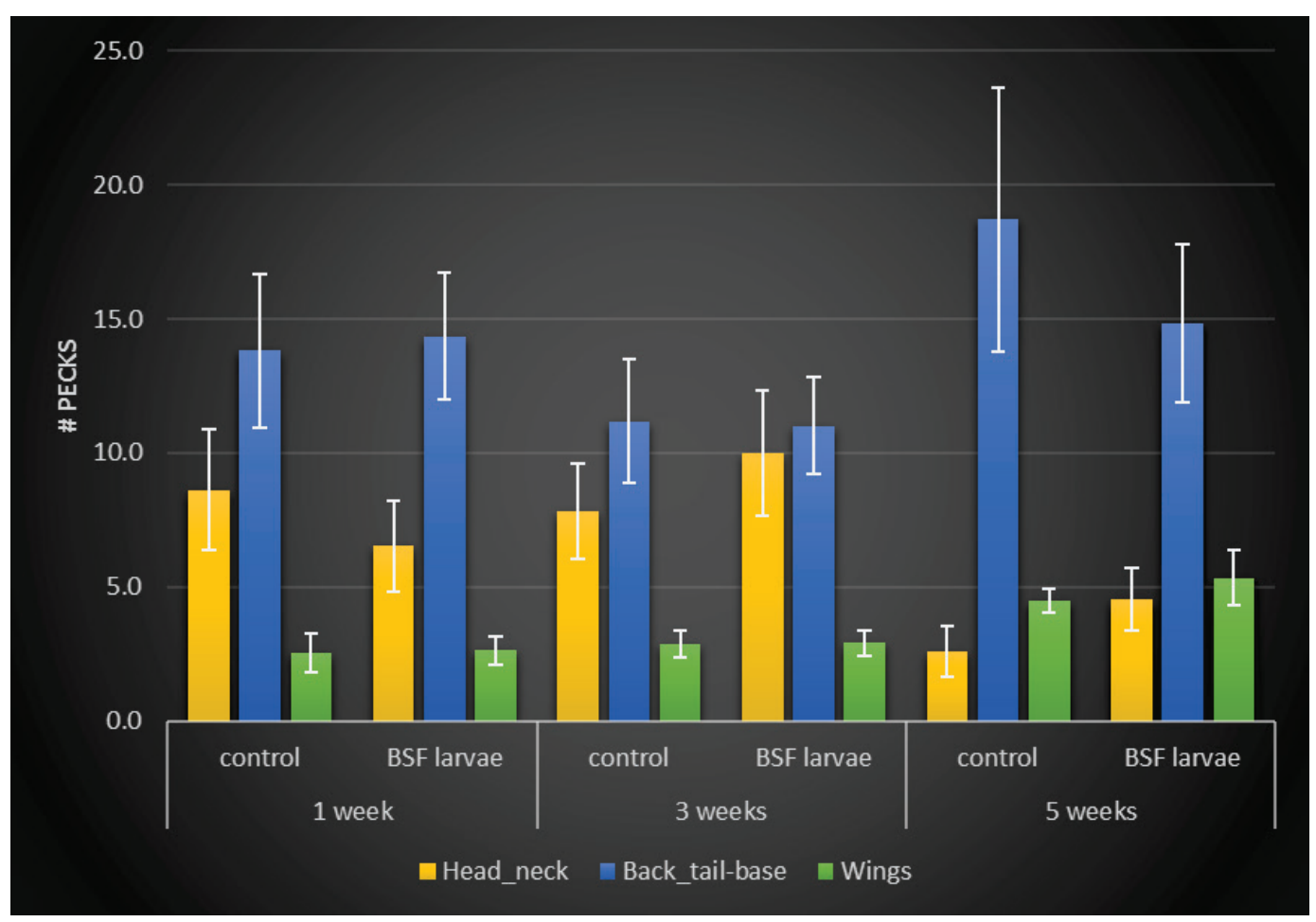

Figure 14 Feather pecking directed towards Head/neck, Back/tail-base and Wings per treatment and per week

The control birds showed significantly more aggressive pecking towards the back and tail-base (figure 15). Aggressive pecking towards the head and neck region was less frequent and not significantly different between the two treatments. Wings were not really targeted and no significant differences were found.

Looking at the behaviour over the day, figure 15 presents aggressive pecking in 3 time frames: 10.00$11.00 \mathrm{~h}, 11.00-12.00 \mathrm{~h}$ and 18.00-19.00 h. The averages are presented over week 1,3 and 5 . BSF larvae were provided at $11.00 \mathrm{~h}$ (i.e. between the first and second time frame). 
No difference between time frames was found for pecks directed towards head/neck and the wings. In the period after provision of BSF larvae no increase of aggression was seen due to possible competition for the BSF larvae. Pecking at the back and tail base significantly increased in the time frame 18.00-19.00 $\mathrm{h}$ for the control group, but not for the BSF larvae group.

Figure 16 shows the results per time frame per week. In weeks 3 and 5 recordings were also made for the time frame 12.00-13.00 h.. No differences were found in wing pecking. Aggressive pecking at head/neck was increased in the time frame 18.00-19.00 h in week 1 for the BSF larvae groups, but not in week 3 . In week 5 the opposite occurred: more pecking in the control groups. As this was a very large effect, this made the average over the weeks lower in the BSF larvae groups (less aggressive pecking in the evening). In week 3 aggressive pecking at head/neck occurred more in the BSF larvae groups before the BSF larvae were provided (10.00-11.00 h) and in the evening (18.00$19.00 \mathrm{~h}$ ). In week 1 and 5 there were no significant differences for aggressive head/neck pecking.

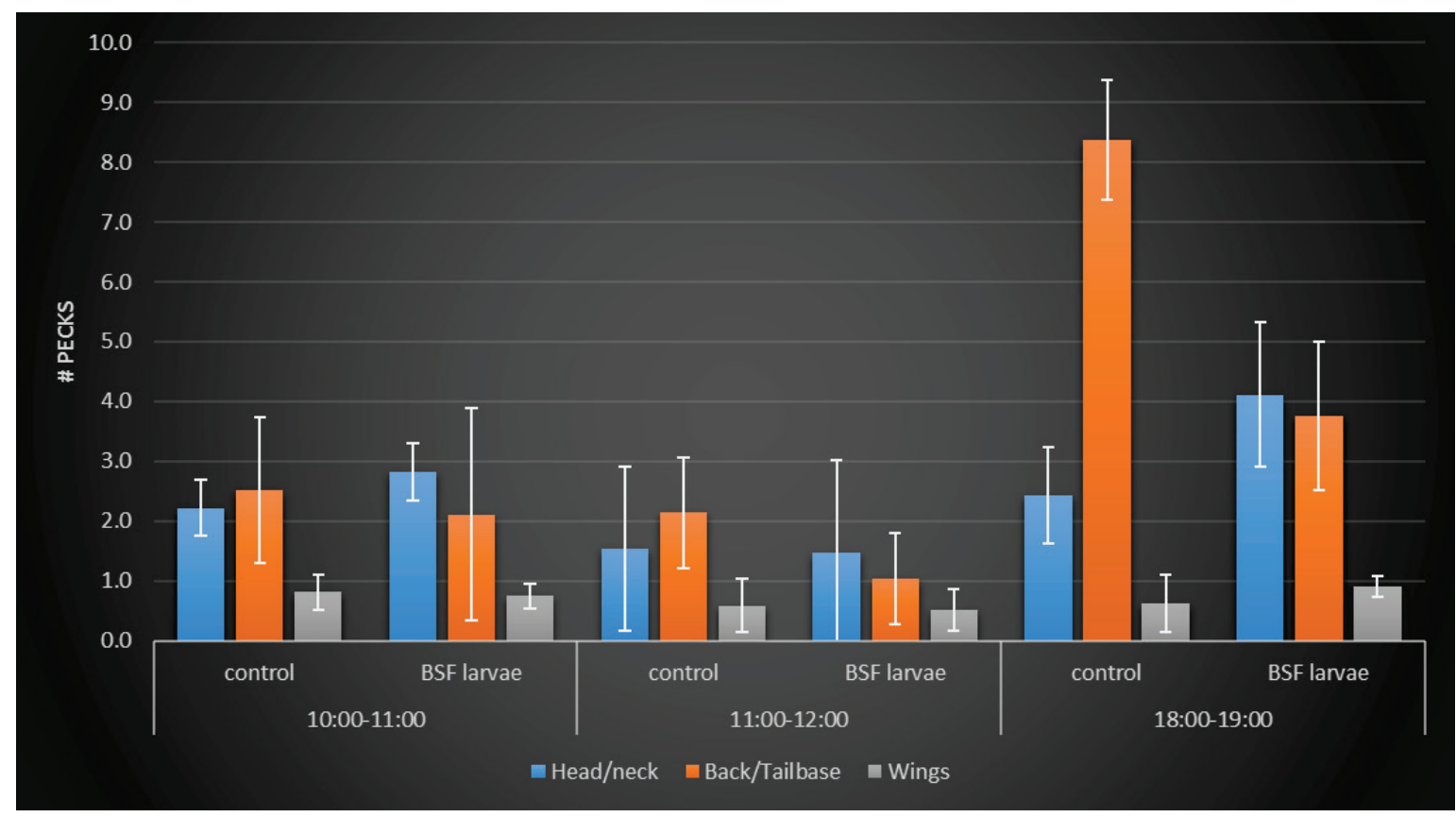

Figure 15 Aggressive pecking directed towards Head/neck, Back/tail-base and Wings per time frame, averaged over week 1, 3 and 5.

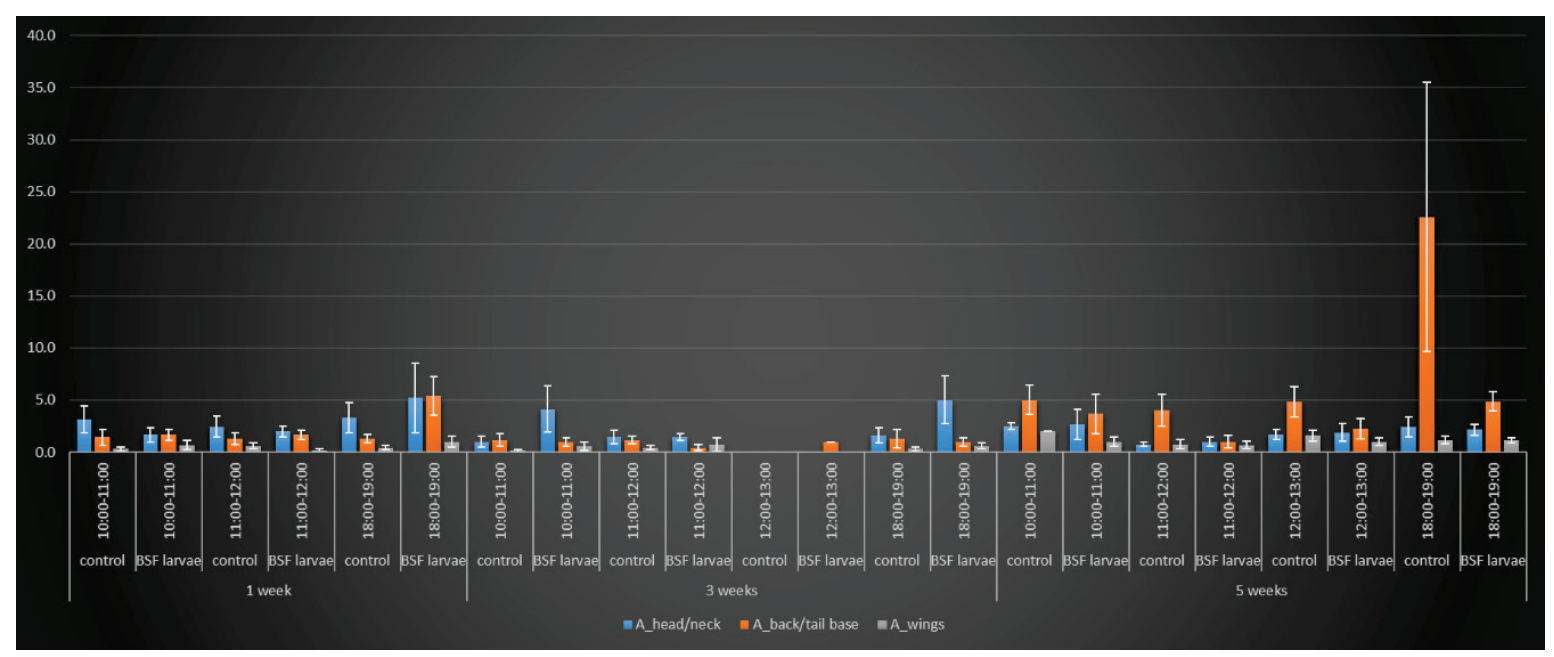

Figure 16 Aggressive pecking directed towards Head/neck (blue), Back/tail-base (orange) and Wings (gray) per time frame and per week

In figure 17 feather pecking is presented for the same time frames, averaged over recordings in week 1,3 and 5. No statistical differences were found for feather pecking towards wings. The BSF larvae group pecked more at the head/neck in the time frame 18.00-19.00 $\mathrm{h}$ than earlier in the day. This was 
not seen in the control group. If the data per week are investigated (figure 18), the effect is visible in week 5, but not in earlier weeks.

Feather pecking at the back and tail base increased over the day, with significantly more feather pecking at 18.00-19.00 h compared to $10.00-11.00 \mathrm{~h}$ with $11.00-12.00 \mathrm{~h}$ being intermediate (figure 17). If the data are split per week (figure 18), the effect can still be seen in weeks 1 and 5 , but not in week 3 . In week 3 the birds seemed to peck less around noon.

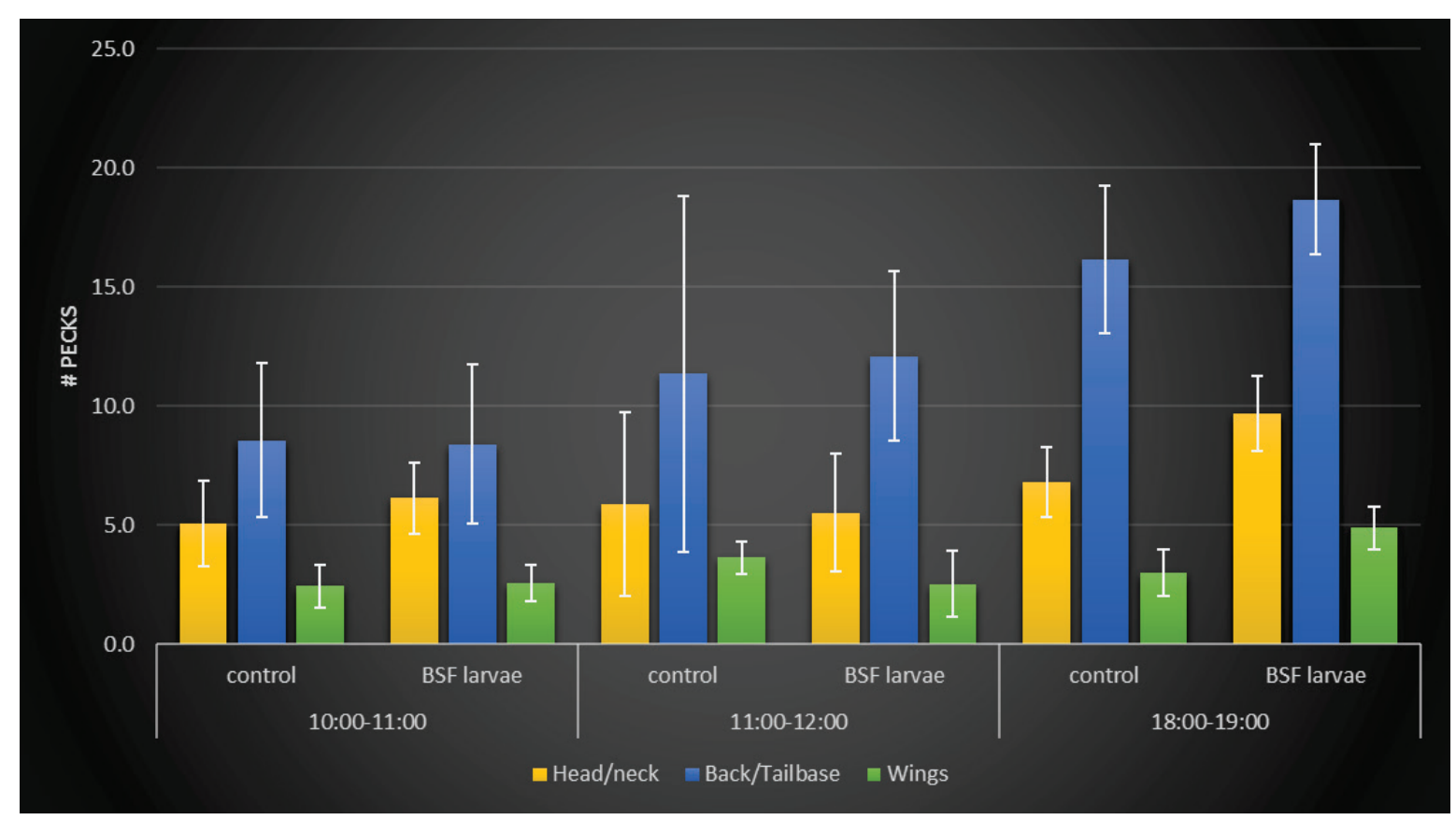

Figure 17 Feather pecking directed towards Head/neck, Back/tail-base and Wings per time frame, averaged over week 1, 3 and 5.

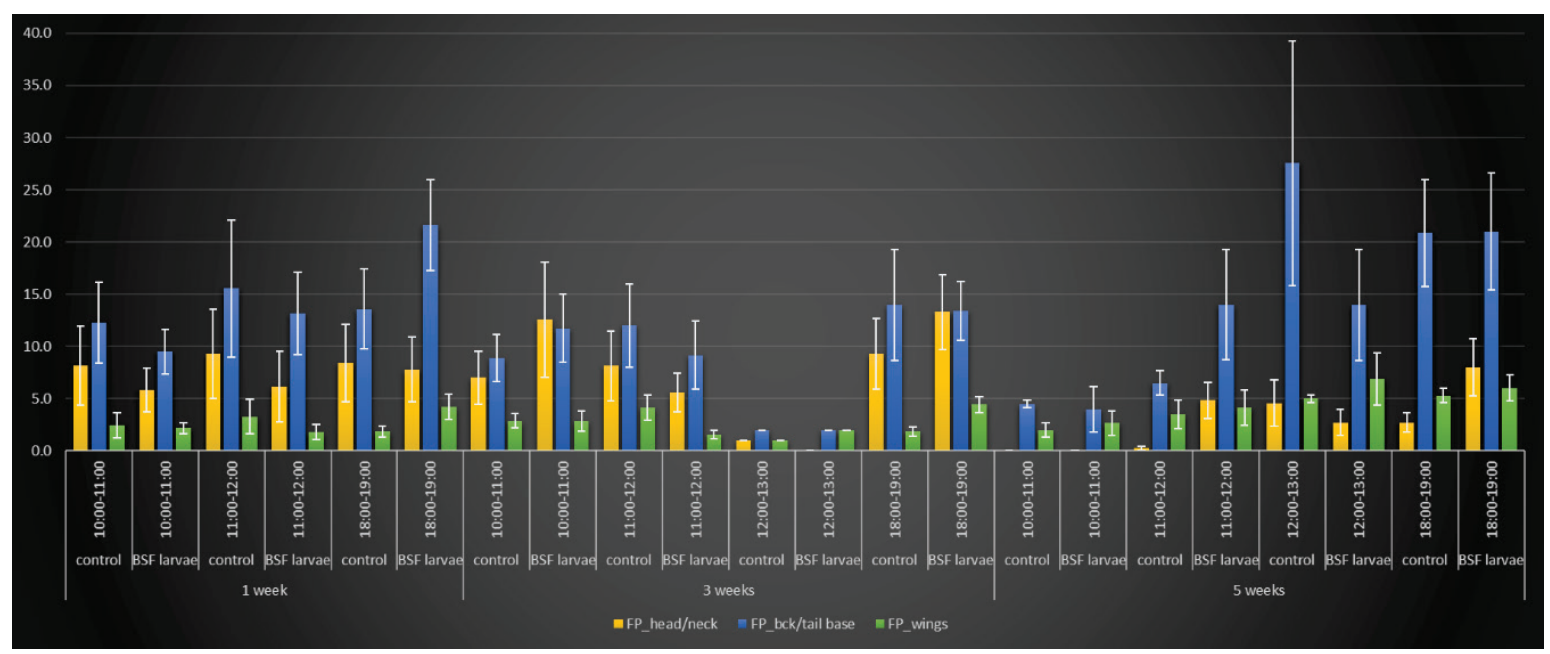

Figure 18 Feather pecking directed towards Head/neck (yellow), Back/tail-base (blue) and Wings (green) per time frame and per week 
Aggressive and feather pecking at the back/tail base averaged over weeks and time of the day was significantly lower in the BSF larvae groups compared to controls (table 6).

Table 6 Overall average aggressive and feather pecking (averaged over weeks and time of day; with SEM)

\begin{tabular}{|c|c|c|c|c|c|c|}
\hline & \multicolumn{3}{|c|}{ Aggression } & \multicolumn{3}{|c|}{ Feather Pecking } \\
\hline & Head/neck & Back/tail base & Wings & Head/neck & Back/tail base & Wings \\
\hline Control & $2.0 \pm 0.3$ & $4.3 \pm 1.7^{a}$ & $0.7 \pm 0.1$ & $6.4 \pm 1.1$ & $14.4 \pm 2.0$ & $3.3 \pm 0.3$ \\
\hline BSF larvae & $2.6 \pm 0.5$ & $2.1 \pm 0.3^{b}$ & $0.7 \pm 0.1$ & $7.0 \pm 1.1$ & $13.3 \pm 1.4$ & $3.7 \pm 0.5$ \\
\hline
\end{tabular}

$a, b$ : different letters indicate a significant difference $(p<0.05)$

In conclusion it can be stated that although the differences were small, the provision of BSF larvae reduced aggressive pecking, especially in periods of the day where no BSF larvae were provided. When BSF larvae were provided no immediate increase of aggression was seen related to competition for the BSF larvae.

\subsection{Visual litter quality}

In general, litter quality was good, as indicated by low friability and wetness scores (table 7). Dietary treatment did not affect litter friability and wetness at $35 \mathrm{~d}$ of age.

Table $7 \quad$ Litter friability and litter wetness at $35 \mathrm{~d}$ of age

\begin{tabular}{crrrr} 
& $\begin{array}{c}\text { BSF Larvae } \\
\text { fed turkeys }\end{array}$ & \multicolumn{2}{c}{$\begin{array}{c}\text { Control } \\
\text { fed turkeys }\end{array}$} & P-value \\
\hline Friability & 2.9 & 3.0 & 1.0 & 0.761 \\
Wetness & 1.7 & 1.9 & 0.7 & 0.663 \\
\hline
\end{tabular}




\section{Conclusions}

- Turkeys were very eager to eat live BSF larvae. Consumption of BSF larvae started immediate after provision. All provided BSF larvae were consumed between one and two minutes after provision and no left-overs of BSF larvae were observed.

- Daily provision of live BSF larvae fed at $12 \%$ of the daily feed ration resulted in a significantly higher feed intake, body weight gain and a significantly lower feed conversion in turkeys in the period from 0 to 35 days age.

- $\quad$ The positive effect of $12 \%$ BSF larvae supplementation on feed conversion ratio was most pronounced in the period until 15 days of age.

- $\quad$ Feather and skin damage in week 4 and 5 was lower in the larvae groups.

- Overall cleanliness of the feathers was not different between the control and larvae groups.

- The incidence of foot pad lesions increased over age. They were more frequent in the control group in the first 3 weeks, but after that there was no difference anymore.

- $\quad$ Birds fed BSF larvae showed less foraging behaviour in the third and fifth week compared to the controls, whereas in the first week there was a tendency for more foraging behaviour in the BSF larvae groups.

- For activities other than foraging no clear trends could be observed.

- Feeding the larvae reduced the frequency of aggressive pecking directed at the back and tail base, especially at 5 weeks of age. This effect was not so much around the time of feeding, but later in the day.

- With regards to feather pecking no clear differences between the groups were found.

- Visual litter quality was not affected by dietary treatment at $35 \mathrm{~d}$ of age. 


\section{References}

Grigor, P.N., B.O. Hughes, M.J. Gentle, 1995. An experimental investigation of the costs and benefits of beak trimming in turkeys. Veterinary Record (1995) 136, 257-265.

Hendrix Genetics. 2017. Performance Goals Converter Commercial Males. Download www.hybridturkeys.com

Hocking, P.M., R.K. Mayne, R.W. Else, N.A. French, J. Gatchlife. 2008. Standard European footpad dermatitis scoring system for use in turkey processing plants. World's Poult. Sci. J. 64, 323-328.

Spindler, B., J. Hartung, and C. Habig, 2013. Gegenwärtige Management- und Haltungsbedingungen bei nicht schnabelgekürzten Puten in der ökologischen Haltung. Abschlussberichtd. Stiftung Tierärztliche Hochschule Hannover Institut für Tierhygiene, Tierschutz und Nutztierethologie. 41 p.

Van Niekerk, Thea and Marc B. M. Bracke, 2016. Pikkerij bij kalkoenen -Een stap terug naar het natuurlijk gedrag en soortspecifieke eigenschappen [Pecking in turkeys - A step back to natural behaviour and species-specific characteristics]. Wageningen Livestock Research. Report. Available at http://edepot.wur.nl/388876, accessed 12-9-17.

Veldkamp, T. 2012. Omgevingsverrijking voor vleeskalkoenen = Environmental enrichment for turkeys. Lelystad: Wageningen UR Livestock Research. Report 651: 15 p. 


\section{Appendix 1 Feed composition of experimental turkey diet during phase I}

Corn

Soybean meal

Corn gluten mea

Fish meal CP > 680

Corn starch

Soy oil

Limestone (fine)

Mono-Calcium phosphate

Salt

Sodiumbicarbonate

Potassiumcarbonate

Starter premix 254 turkeys, corn

Natuphos 10000 G; 0,05 g/kg

L-Lysine $\mathrm{HCl}$

DL-Methionine

L-Threonine

L-Tryptophan

L-Arginine

L-Valine

Total

Nutrients

DM

CAsh

CP

CFath

Cfibre

STARCHam

SUG

NSP

OEbroiler

C18:2

$\mathrm{Ca}$

IP

OP

Ca : oP

$\mathrm{Mg}$

$\mathrm{Na}$

$\mathrm{K}$

EB

LYS

MET

CYS

$\mathrm{M}+\mathrm{C}$

THR

TRP
ILE

ARG

PHE

HIS

LEU

TYR

VAL

ASP

GLU

GLY

PRO

SER

Sum_AA

dLYSp

dMETp

dCYSp

$\mathrm{dM}+\mathrm{Cp}$

dTHRp

dTRPp

dILEp

dARGp

dPHEp

dHISp

dLEUp

dTYRp

dVALp

BSF: Black Soldier Fly larvae)
Diet without BSF

$\%$

Diet to be supplemented with $10 \%$ BSF

30.97

21.22

30.27

5.00

5.00

0.00

1.39

1.88

1.88
2.43
0.03

0.28

0.00

0.50

0.01

0.49

0.26

0.11

0.01

0.13

0.02

100.00

$\%$

0,00

11,11

32,93

9,68

5,56

30,12

3,49

2,00

2.79

0.03

0,30

0,22

0.56

0.01

0.53

0,31

0,11

0,02

0,21

100,00

calculated

884.9

83.6

275.0

44.1

24.0

317.1

40.8

129.7

11.50

15.3

13.75

10.32

2.33

7.37

1.87

1.58

1.67

9.41

2.60

240

17.79

7.31

4.18

11.52

11.08

3.02

11.34

17.94

13.38

6.96

23.84

9.83

12.84

14.36

25.61

49.21

11.53

16.63

12.98

269.45

15.92

6.85

3.47

10.32

9.43

2.65

9.82

16.11

11.84

6.02

21.10

8.64

11.00 analysed

882.7

73.3

267.2

45.6

26.0

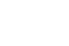

13.74

10.34

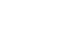

16.84

7.18

3.88

11.06

11.00

3.44

11.67

17.11

13.43

7.81

24.48

10.30

12.74

14.35

24.77

48.39

11.19

17.34

12.39

268.32 calculated analysed

891,9

89,5

288,2

52,9

16,9
333,4

37,2

92,7

12,24

20,9

15,79

10,72

1,86

8,95

1,76

1,37

1,81

9,94

2,64
258

18,65

8,08

4,13

12,24

11,49

3,21

12,03

19,14

14,30

6,98

26,08

10,68

13,22

15,40

27,00

50,48

11,69

16,81

13,60

282,56

14.73

10.55

17.50

8.04

4.08

12.12

3.73

12.47

18.38

14.47

7.96

26.92

11.25

13.33

15.55

26.16

50.38

11.50

18.64

13.09

284.92
11.47 


\section{Appendix 2 Feed composition of experimental turkey diet during phase II}

Diet without BSF $\%$

Corn

Wheat

Soybean meal

Corn gluten meal

Fish meal CP > 680

Corn starch

Soy oil

Limestone (fine)

Mono-Calcium phosphate

Salt

Sodiumbicarbonate

Potassiumcarbonate

Starter premix 254 turkeys, corn

Natuphos $10000 \mathrm{G} ; 0,05 \mathrm{~g} / \mathrm{kg}$

L-Lysine $\mathrm{HCl}$

DL-Methionine

L-Threonine

L-Tryptophan

L-Arginine

L-Valine

Total

Nutrients

DM

CAsh

CP

CFath

Cfibre

STARCHam

SUG

NSP

OE broiler

C18:2

$\mathrm{Ca}$

$\mathrm{P}$

IP

oP

Ca : oP

$\mathrm{Mg}$

$\mathrm{Na}$

$\mathrm{K}$

$\mathrm{Cl}$

EB

LYS

MET

CYS

$\mathrm{M}+\mathrm{C}$

THR

TRP

ILE

PHE

LEU

TYR

VAL

ALA

GLU

GLY

PRO

SER

Sum_AA

dLYSp

dMETp

dCYSp

$\mathrm{dM}+\mathrm{Cp}$

dTHRp

dTRPp

dILEp

dARGp

APHEp

dHISp

dLEUp

dTYRp

dVALp
29,42

22,00

32,63

6,67

0,00

0,00

1,95

2.61

0,15

0.00

0.50

0,55

0,24

0,00

0,08

0,00

100,00

885.0

82.6

260.0

53.8

315.2

43.3

135.2

11.70

22.6

13.07

9.70

2.46

6.98

1.87

1.55

1.67

9.47

2.65

240

16.39

4.21

10.72

10.16

2.81

10.79

16.54

13.22

6.55

23.75

9.67

11.91

13.48

24.26

48.89

9.98

16.59

12.67

257.98

14.65

6.06

3.48

9.54

8.65

2.46

9.36

14.75

11.76

5.65

21.00

8.53

10.15
Diet to be supplemented with $10 \%$ BSF

$\%$

7,49

5,56

35,43

11,56

0,00

27,78

4,69

2,09

3.00

0,16

0.20

0.56

0.01

0,60

0,29

0,08

0,02

0,16

0,00

100,00

881.5

69.4

255.8

56.3

26.2

891,8

88,5

271,5

62,9

18,3

331,8

39,2

99,9

12,46

28,5

12.63

15,05

10,06

2,03

8,52

1,77

1,34

1,84

9,93

2,66

259

17,14

4,17

11,43

10,42

2,97

11,41

17,56

14,14

6,57

26,39

10,56

12,33

14,71

25,57

49,39

9,96

16,72

13,26

270,09

13.81

10.18

16.33

7.15

4.08

11.23

3.38

12.07

17.01

14.45

7.74

27.55

11.17

12.54

15.03

25.09

49.94

9.96

18.25

12.76

275.07 


\section{Appendix 3 Composition turkey premix}

\begin{tabular}{|c|c|c|c|}
\hline Parameter & Results & Unit & \\
\hline Retinol & 16,000 & IE & \\
\hline Cholecalciferol & 4.200 & IE & \\
\hline DL-a-tocopherol & 40 & $\mathrm{mg}$ & \\
\hline Menadione & 4,0 & $\mathrm{mg}$ & \\
\hline Thiamine & 4,0 & $\mathrm{mg}$ & \\
\hline Riboflavin & 8,0 & $\mathrm{mg}$ & \\
\hline Pyridoxine-HCl & 4,0 & $\mathrm{mg}$ & \\
\hline Cyanocobalamine & 25 & $\mu g$ & \\
\hline Ascorbic acid & 10 & $\mathrm{mg}$ & \\
\hline Niacin & 75 & $\mathrm{mg}$ & \\
\hline D-pantothenic acid & 20 & $\mathrm{mg}$ & \\
\hline Choline chloride & 1.000 & $\mathrm{mg}$ & \\
\hline Folic acid & 1,0 & $\mathrm{mg}$ & \\
\hline Biotin & 0,1 & $\mathrm{mg}$ & \\
\hline Iron & 50 & $\mathrm{mg}$ & $\left(170 \mathrm{mg} \mathrm{FeSO}{ }_{4} \cdot \mathrm{H}_{2} \mathrm{O}\right)$ \\
\hline Copper & 12 & $\mathrm{mg}$ & $\left(50 \mathrm{mg} \mathrm{CuSO}_{4} .5 \mathrm{H}_{2} \mathrm{O}\right)$ \\
\hline Manganese & 90 & $\mathrm{mg}$ & (150 mg MnO) \\
\hline Zinc & 60 & $\mathrm{mg}$ & $\left(170 \mathrm{mg} \mathrm{ZnSO}{ }_{4} \cdot \mathrm{H}_{2} \mathrm{O}\right)$ \\
\hline Cobalt & 0,2 & $\mathrm{mg}$ & $\left(1,0 \mathrm{mg} \mathrm{CoSO} \mathrm{C}_{4} \cdot 7 \mathrm{H}_{2} \mathrm{O}\right)$ \\
\hline Iodine & 0,8 & $\mathrm{mg}$ & $(1,0 \mathrm{mg} \mathrm{KJ})$ \\
\hline Selenium & 0,1 & $\mathrm{mg}$ & $\left(0,22 \mathrm{mg} \mathrm{Na} \mathrm{SeSO}_{3}\right)$ \\
\hline Anti-oxidant & 125 & $\mathrm{mg}$ & \\
\hline
\end{tabular}




\section{Appendix 4 Certificate of analysis life frozen Black Soldier Fly}

(Protix Biosystems, March 23, 2015)

\begin{tabular}{|c|c|c|}
\hline Parameters & Results & Units \\
\hline Moisture & 67.7 & $\%$ \\
\hline Protein & 15.6 & $\%$ \\
\hline Fat & 12.4 & $\%$ \\
\hline Fibre & 2.5 & $\%$ \\
\hline Ash & 1.6 & $\%$ \\
\hline Calcium & 0.2186 & $\%$ \\
\hline Phosphorus & 0.2179 & $\%$ \\
\hline Sodium & 0.0299 & $\%$ \\
\hline Potassium & 0.3276 & $\%$ \\
\hline Chloride & 0.07 & $\%$ \\
\hline LYS & 8.1 & $\mathrm{~g} / \mathrm{kg}$ \\
\hline MET & 2.7 & $\mathrm{~g} / \mathrm{kg}$ \\
\hline CYS & 0.9 & $\mathrm{~g} / \mathrm{kg}$ \\
\hline$M+C$ & 3.6 & $\mathrm{~g} / \mathrm{kg}$ \\
\hline THR & 6.0 & $\mathrm{~g} / \mathrm{kg}$ \\
\hline TRP & n.d. & $\mathrm{g} / \mathrm{kg}$ \\
\hline ILE & 6.4 & $\mathrm{~g} / \mathrm{kg}$ \\
\hline ARG & 6.1 & $\mathrm{~g} / \mathrm{kg}$ \\
\hline PHE & 6.6 & $\mathrm{~g} / \mathrm{kg}$ \\
\hline HIS & 3.6 & $\mathrm{~g} / \mathrm{kg}$ \\
\hline LEU & 9.7 & $\mathrm{~g} / \mathrm{kg}$ \\
\hline TYR & 9.2 & $\mathrm{~g} / \mathrm{kg}$ \\
\hline VAL & 9.0 & $\mathrm{~g} / \mathrm{kg}$ \\
\hline ALA & 10.9 & $\mathrm{~g} / \mathrm{kg}$ \\
\hline ASP & 12.4 & $\mathrm{~g} / \mathrm{kg}$ \\
\hline GLU & 13.6 & $\mathrm{~g} / \mathrm{kg}$ \\
\hline GLY & 7.4 & $\mathrm{~g} / \mathrm{kg}$ \\
\hline PRO & 5.8 & $\mathrm{~g} / \mathrm{kg}$ \\
\hline SER & 5.3 & $\mathrm{~g} / \mathrm{kg}$ \\
\hline Sum amino acids & 12.59 & $\mathrm{~g} / \mathrm{kg}$ \\
\hline
\end{tabular}




\section{Appendix 5 Light management}

$\begin{array}{ll}\text { Day } 1 & 23 \mathrm{~L}: 1 \mathrm{D} \\ \text { Day 2 } & 22 \mathrm{~L}: 2 \mathrm{D} \\ \text { Day 3 } & 21 \mathrm{~L}: 3 \mathrm{D} \\ \text { Day 4 } & 20 \mathrm{~L}: 4 \mathrm{D} \\ \text { Day 5 } & 19 \mathrm{~L}: 5 \mathrm{D} \\ \text { Day } 6 & 18 \mathrm{~L}: 6 \mathrm{D} \\ \text { Day 7 } & 17 \mathrm{~L}: 7 \mathrm{D} \\ \text { Day } 8-35 & 16 \mathrm{~L}: 8 \mathrm{D}\end{array}$




\section{Appendix 6 Room/local temperature settings}

$\begin{array}{ll}\text { room } & \text { local } \\ \text { temperature } & \text { temperature } \\ { }^{\circ} \mathrm{C} & { }^{\circ} \mathrm{C}\end{array}$

$\begin{array}{lll}\text { day } 1 & 28 & 36 \\ \text { day } 2 & 28 & 35 \\ \text { day } 3 & 28 & 34 \\ \text { day } 4 & 27 & 33 \\ \text { day } 5 & 26 & 32 \\ \text { day } 6 & 26 & 31 \\ \text { day } 7 & 25 & 30 \\ \text { day } 8 & 24 & 29 \\ \text { day } 9 & 24 & 28 \\ \text { day } 10 & 24 & 27 \\ \text { day } 11 & 24 & 26 \\ \text { day } 12 & 24 & 26 \\ \text { day } 13 & 24 & 26 \\ \text { day } 14 & 24 & - \\ \text { day } 21 & 23 & - \\ \text { day } 28 & 22 & -\end{array}$



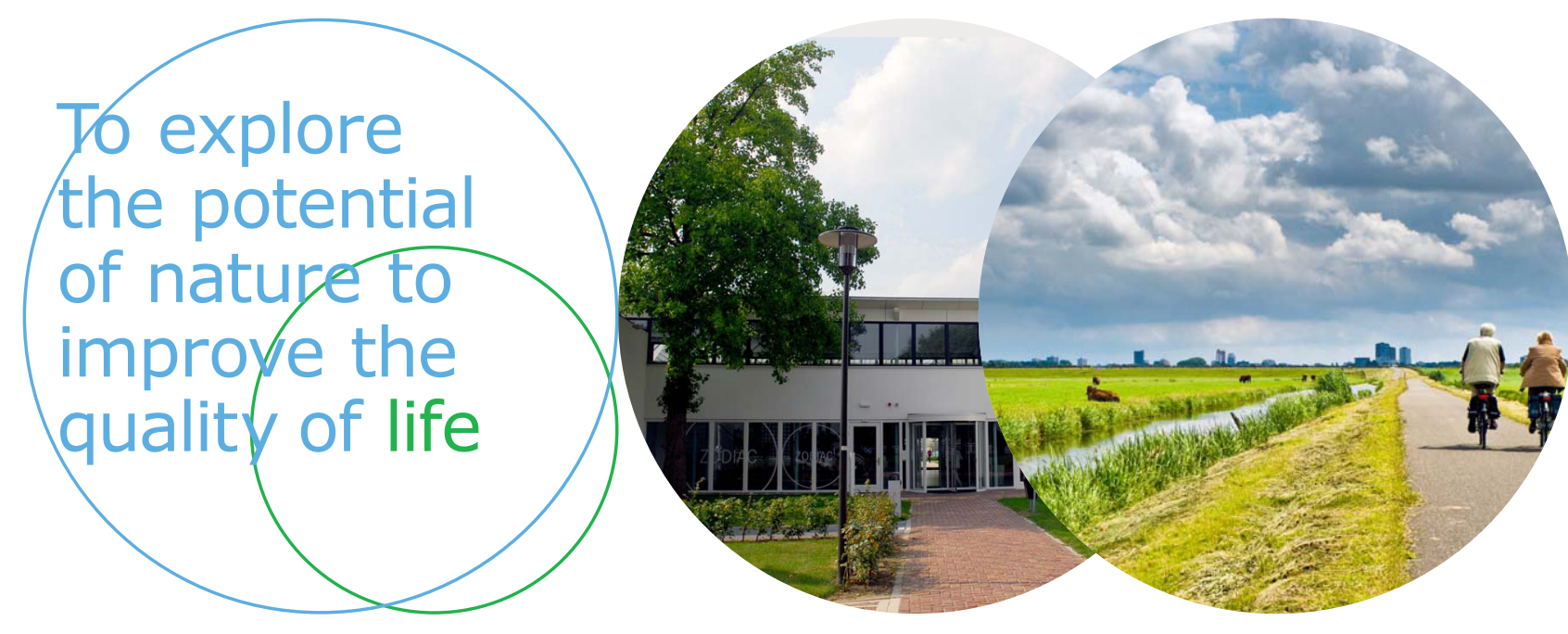

Wageningen Livestock Research P.O. Box 338

$6700 \mathrm{AH}$ Wageningen

The Netherlands

T +31 (0)31748 3953

E info.livestockresearch@wur.nl

www.wur.nl/livestock-research

Wageningen Livestock Research creates science based solutions for a sustainable and profitable livestock sector. Together with our clients, we integrate scientific knowledge and practical experience to develop livestock concepts for future generations.

Wageningen Livestock Research is part of Wageningen University \& Research. Together we work on the mission: 'To explore the potential of nature to improve the quality of life'. A staff of 6,500 and 10,000 students from over 100 countries are working worldwide in the domain of healthy food and living environment for governments and the business community-at-large. The strength of Wageningen University \& Research lies in its ability to join the forces of specialised research institutes and the university. It also lies in the combined efforts of the various fields of natural and social sciences. This union of expertise leads to scientific breakthroughs that can quickly be put into practice and be incorporated into education. This is the Wageningen Approach. 